\title{
Global Microstructures: The Virtual Societies of Financial Markets ${ }^{1}$
}

\author{
Karin Knorr Cetina \\ University of Konstanz \\ Urs Bruegger \\ University of St. Gallen
}

\begin{abstract}
Using participant-observation data, interviews, and trading transcripts drawn from interbank currency trading in global investment banks, this article examines regular patterns of integration that characterize the global social system embedded in economic transactions. To interpret these patterns, which are global in scope but microsocial in character, this article uses the term "global microstructures." Features of the interaction order, loosely defined, have become constitutive of and implanted in processes that have global breadth. This study draws on Schutz in the development of the concept of temporal coordination as the basis for the level of intersubjectivity discerned in global markets. This article contributes to economic sociology through the analysis of cambist (i.e., trading) markets, which are distinguished from producer markets, and by positing a form of market coordination that supplements relational or network forms of coordination.
\end{abstract}

Global financial markets are recent phenomena that embrace global capital and commodity markets, as well as foreign exchange markets. With an average daily turnover in traditional global foreign exchange instru-

\footnotetext{
'Our greatest debts lie with the managers, traders, salespersons, and analysts at the bank herein designated " $\mathrm{GB1}$ " and two other banks, whose help proved invaluable in making this study possible and who were so generous in sharing information with us. We gratefully acknowledge the helpful comments, suggestions, and ideas provided by Klaus Amann, Paul DiMaggio, Frank Dobbin, Stefan Hirschauer, Michèle Lamont, John Lie, Andrew Pickering, Alexandru Preda, Harrison White, Viviana Zelizer, Eviatar Zerubiavel, and many others when earlier drafts were presented at seminars and at the 1998 meeting of the American Sociological Association in San Francisco, where Charles Smith provided especially detailed and constructive comments. Karin Knorr Cetina prepared this article while she was visiting the Department of Sociology,
} 
ments of $\$ 1.5$ trillion in April 1998, up from $\$ 1.2$ trillion in 1995 and $\$ 36.4$ billion in 1974 , they have proved to be the fastest-growing and most important element in the shaping of the global structure of financial markets over the past decade (BIS 1998, pp. 1-3; Gosh and Ortiz 1997, pp. 10-14). Unlike other financial markets, the foreign exchange market is not organized mainly in centralized exchanges but derives predominantly from interdealer transactions in a global banking network of institutions. ${ }^{2}$ As collective disembodied systems generated entirely in a symbolic space, these markets can be seen as an icon of contemporary global hightechnology professional cultures. Yet we know very little about these cultures, which raise important questions for economists, who consider exchange rates to be a significant catalyst of global markets with farreaching effects on the income, wealth, and welfare of communities. So far, however, economists have not been satisfied with attempts to model the determinants and movements of these rates (e.g., Koundinya 1997, p. 185). These cultures also raise important questions for sociologists, not the least of which is how we are to understand the global social systems embedded in the respective economic transactions. It is important to realize that we are indeed confronted with global social systems here. Traders are the major operators in international currency markets, and they are interconnected by high-technology communication in real time, passing their "books," when accounts are not closed in the evening, from time zone to time zone, following the sun. This situation has to be distinguished from that of dispersed brokerage communities in major exchanges, in which members do not exhibit high-frequency dynamic interaction with one another across countries and exchanges. Traders in interbank currency dealing do not broker deals but trade for their banks' accounts via direct dealer-to-dealer contact or via electronic brokerage systems disengaged from local settings. To date, sociologists have not investigated these collective arrangements, although some excellent early studies of national securities and bond markets exist and provide an important basis for such studies (e.g., Smith 1981, 1999; Baker 1984; Abolafia 1996a, 1996b). In this article, we begin to develop an analysis of international currency

Princeton University, and she was supported by a grant from the Deutsche Forschungsgemeinschaft. Direct correspondence to Karin Knorr Cetina, Department of Sociology, Universitet Konstanz, Box D-46, D-78457 Konstanz, Germany. E-mail: karin.knorr@uni-konstanz.de

${ }^{2}$ In 1998, dealers on the trading floor of the Global Investment Bank estimated that they were dealing with approximately 50 institutions that made up this network. The numbers vary substantially over time, as mergers and other movements reduce (or raise) the number of institutions. According to BIS (Bank of International Settlements) statistics, $63 \%$ of the deals derive from interdealer business (BIS 1998, p. 2). 
markets as global social forms. ${ }^{3}$ To do this, we will draw on two literatures that we also hope to extend in structuring a view of these markets: one is the area of economic sociology concerned with markets, and the other is microsociology.

\section{THE MICROSOCIOLOGICAL APPROACH TO GLOBAL SOCIAL. FORMS: SOME CONCEPTS}

Since microsociology has not traditionally been thought of as particularly pertinent to issues of globalization or to the understanding of markets when they are stretched out in geographical space, some explanation is necessary to clarify the precise nature of microsociology's relevance and the contribution that can be made to it in this area. What we suggest in this article is that fields in which participants, although geographically distant, are oriented, above all, toward one another and, at the same time, disengaged from local settings are spanned and bound together by global microstructures-that is, patterns of relatedness and coordination that are global in scope but microsocial in character and that assemble and link global domains. We argue that features of the interaction order, loosely defined, have become constitutive of and implanted in processes that have global breadth; microsocial structures and relationships are what instantiate some of the most globally extended domains-for example, global financial markets. In the last few decades, we have witnessed a rise to structural equivalence of what Goffman called the interaction order and macrosocial phenomena. ${ }^{4}$ The rise to equivalence came with an understanding of forms of life in the interaction order as relatively autonomous and not prior to, fundamental to, or constitutive of the shape of macroscopic phenomena (Goffman 1983, p. 9; Collins 1981; Knorr Cetina 1981). It also came with an understanding of the microworld as situational and

\footnotetext{
${ }^{3}$ In focusing on markets as social forms, we necessarily exclude questions of the aggregate social and economic consequences-on exchange rates and on the wealth of nations and populations-that arise when enormous amounts of money are being traded. These questions are important, but they would require an entirely different approach-e.g., the analysis of exchange-rate movements in relation to indicators of income, spending, investments, pension levels, etc. In other words, answers to such questions do not simply emerge from traders' rationales for making particular deals or from banks' rationales for acting as market makers in foreign exchange. Such questions are at least partially addressed by economists and governments (e.g., Hills, Peterson, and Goldstein 1999), although, as suggested, economists also think that they are as yet ill understood.

${ }^{4}$ As Goffman explained in his 1982 presidential address to the American Sociological Association (1983, p. 2, emphasis in the original), "My concern over the years has been to promote acceptance of this face-to-face domain as an analytically viable one, a domain which might be titled, for want of any happy name, the interaction order."
} 


\section{American Journal of Sociology}

tied to the concrete social setting and the social occasion, which were thought to be governed by principles and dynamics not simply continuous with or deducible from macrosocial variables. Goffman defined the situation as "any physical area anywhere within which two or more persons find themselves in visual and aural range of one another" (1972, p. 63; 1981, p. 84). ${ }^{5}$ Ethnomethodologists have expressed similar ideas through the notion of the local accomplishment of social order, in which "local" means witnessable, through seeing or hearing, in contrast to imputed or inferred. ${ }^{6}$ This article argues for an extension of microview points that are pitched at the level of the local and the situation as the prime social reality, to larger settings. If the hallmark of microsociology in the past was its emphasis on local social forms, then we should extend the field to corresponding research on genuinely global social forms. The assumptions that have characterized much microsociological thinking in the past-those of the relative autonomy of micro-orders and their confinement to the physical setting - are theoretically no longer adequate in a world in which interaction can also be disembedded from local settings, in which space may be separated from place (Giddens 1990, p. 18) and in which situations may link participants who are physically located in different continents and time zones. ${ }^{7}$ What appears necessary today is that we rechart this territory in ways that include distantiated spatial configurations. Some microsociological notions, such as witnessing or situation, would seem to extend naturally to distant realities as long as these realities can be mutually represented to individuals participating in a global situation.

An important purpose of this article thus is to contribute to the opening up of microsociology for global studies by offering an analysis of a global

\footnotetext{
${ }^{5}$ There is a significant body of literature that deals with aspects of the interaction order (for overviews of important dimensions, see Stone and Farberman [1981], Fine [1984], and Scheff [1990]). Our purpose is merely to indicate some of those features that seem to be central to the creation of global spheres and that need to be respecified in regard to this context. There are also now interesting bodies of work on humanmachine interaction (e.g., Suchman 1987; Turkle 1995) and of related ethnomethodological studies of work (for overviews, see Ten Have and Psathas [1995] and Button [1993]; see also Goodwin 1995), but our focus is instead on transactions in which the computer becomes transparent and in which third parties are charged with guaranteeing its (and the software's) functionality.

"This formulation is suggested by the ethnomethodologist Anne Warfield Rawls (oral communication, August 15,2000). The emphasis on witnessability derives from Garfinkel (e.g., 1967, pp. 9-13). The only published ethnomethodological study of financial market practices that we are aware of focuses on the local organization of tradingroom cooperation (Heath et al. 1994).

'Giddens (1990, pp. 21-29) used the notion of disembedding to refer to the "lifting out of social relations from local contexts." Here, we are concerned with how interaction principles traditionally associated with local contexts shape global domains,
} 
social form in terms of concepts that not only draw on microsociology but also will have to be extended and supplemented to capture global configurations. The basic insight that motivates this undertaking and for which we will herein provide evidence is that global social forms-by which we mean fields of interaction that stretch across all time zones (or have the potential to do so)-need not imply further expansions of social complexity along the lines of highly differentiated organizations or complex social control and authority structures. Rather, the installation of global social forms that are not nationally bound would seem to be largely dependent on individuals and social microstructures. Perhaps it only becomes feasible at all in relation to such structures. To characterize these structures, we have introduced a distinction between embodied presence and response presence--that is, embodied presence corresponds to the face-to-face situation, while response presence corresponds to situations in which participants are capable of responding to one another and common objects in real time without being physically present in the same place. Electronically mediated encounters and fields, including global fields of institutional interaction such as those studied herein, are exemplars of response-presence-based situations. It seems advantageous to associate response-presence-based social forms that are dispersed in space and potentially global in spread with microsocial concepts (i.e., situations) for the following reasons.

First, as indicated, response-presence-based social forms are bound together by electronic information technologies (Dutton 1996), the arteries of global and transnational connectedness through which the interactions flow. The idea of global microstructures responds to the perception that dispersed domains linked by information technologies tend to be drawn together as if they were in one place. This drawing together is achieved through the speed of signal transmission and through the medium of the screen, on which what is at the other end is appresented. We have borrowed the notion of appresentation from Schutz and Luckmann (1973, p. 11) to emphasize that the screen brings that which is geographically distant and invisible near to participants, thus rendering it interactionally present-in other words, response present. It is also important that the idea of global microstructures captures the sociological side of information technologies: global microstructures instantiate technology systems as sequentially and culturally specific social actions performed from a distance. The technologies themselves tend to be taken as given and transparent for participants who are oriented toward global interaction. In the financial markets studied, these technologies are in the care of specialists who are continually available on trading floors to address any problems and provide the necessary maintenance.

Second, in the domain considered and presumably in others like it, an 
important vehicle of global transactions-and the hub of global relatedness-is the conversation. Traders perform market transactions through conversations, as they themselves call their global interactions, and the important point is that these sequences of utterances do not just convey information but perform economic actions. A condition for the emergence of response-presence-based social forms, which are not "chat clubs" separated from the conduct of business but include these affairs, would seem to be that the transactions that compose the domain are performative (i.e., action performing, see Austin 1962) but dematerialized, which means that they can be accomplished symbolically through, for example, communication structures such as those identified with microsocial situations. In financial markets, this dematerialization is broadly supported by securitization, the conversion into paper of more and more borrowing, which can be bought and sold in a secondary market (e.g., Hamilton 1986, p. 64; Perold 1995, pp. 45-49). In a narrower sense, the dematerialization of transactions is also supported by that of dealing products-that is, by avoiding the physical delivery of securities and payments and instead using a variety of other delivery mechanisms. ${ }^{8}$

Third, microsociology appears relevant to the understanding of transnational fields of transactions that are not aggregated into systems of governance but are structured more in terms of horizontal associations. Markets fall under this category, but so, increasingly, do organizations, with the notion of a network established to capture the phenomenon that business firms are becoming flatter, rely more on teamwork and less on hard rules and narrow job descriptions, and interact in complex and cooperative ways (DiMaggio 2001, p. 19; Fligstein 1990). Networks reflect social relations between actors, but, as White (1992, pp. 65-66) and Fligstein $(1996$, p. 657$)$ note, network approaches also have major limitations. Networks are sparse social structures, and it is difficult to see how they can incorporate the patterns of intense and dynamic conversational interaction, the knowledge flows, and the temporal structuration that we observe in the area studied. The microsociological point of view allows a thick description of the specificities of global social forms that could complement network approaches. An additional characteristic of the markets studied herein, which also suggests interactional means of structuration, is that they are governed by a lex mercatoria-that is, by rules of conduct that are not separated from dealing behavior. Traders are the key operators in these markets and also implement and enforce rules of

\footnotetext{
${ }^{3}$ Examples of other delivery mechanisms include the storage of depositories in a fixed location, the recording of ownership in electronic-book-entry form, or the procedure of "netting"-i.e, of offsetting payment commitments between parties (see Perold 1995, pp. $45-50)$.
} 
conduct in a domain that is not subject to national or international legal regulation.

The distinction between embodied presence and response presence serves as a starting point for an understanding of global microstructured domains. The question that lies at the core of the notion of a responsepresence-based social form that extends across global distances is, What are the possibilities of its inherent connectivity and integration as the key to overcoming the geographical separation of participants? We introduce the notion of a global we relationship that is based on temporal coordination to suggest that a level of microintegration, or intersubjectivity, is possible in global fields. We will also use a second concept, the face-toscreen situation, to show how local settings are configured in terms of an orientation toward distantiated interaction. To further illustrate how we relationships are constructed, we turn to a third element, the responsepresence-based conversation, which is a means to achieve connectedness and to transact in the field studied. We will also illustrate the structural use of interaction means as a means to sustain transnational order. Finally, we propose the notion of anchoring to address the degree to which collective disembodied systems penetrate and reflect embodied experience. While these elements can only be outlined within the confines of this article, they suggest core dimensions of distantiated domains that could inform and extend social theory in the area of virtual society and distributed coordination, a goal that appears to be central in light of the massive emergence and expected further development of responsepresence-based social forms.

\section{INSTITUTIONAL FINANCIAL MARKETS: THREE CHARACTERISTICS}

In addition to contributing to the opening up of microsociology for global studies, this article seeks to extend economic sociology both through the analysis of a global market variant and through our specific approach, which is oriented toward markets as "processual" systems. A central proposition of the new economic sociology on which this article draws is that economic action "is a form of social action" (Swedberg and Granovetter 1992, pp. 6-7; Swedberg 1997, p. 162). In this article, we emphasize three features of the markets studied that specify market action and that we want to add to the characterization of microstructuration. Referred to here are the distinctive features of these markets as "cambist" or trader markets, their intersection with knowledge, and their already-mentioned globality, which needs to be recognized from an economic-sociology point of view as an increasingly important feature of most economic action. We 
stress these characteristics because none of them has received much attention in economic sociology - in which the predominant focus in past market studies has been on producer markets and the firm, as well as on more national or regional networks of relationships. Economics itself, by contrast, has developed distinctive perspectives on finance and international money flows, partly in response to banking and currency crises (e.g., Gyöngyössy 1984; Thaler 1993; Crane et al. 1995; Dormael 1997), and has addressed the knowledge aspects of markets at least since the 1940s (e.g., Hayek 1945). Since these features are constitutive of the financial markets studied, we will review them before turning to the trading-floor situation.

First, consider the nature of foreign exchange markets as cambist markets. Economic sociology defines economic behavior in terms of the institutions and the relations of production, consumption, and social distribution (DiMaggio 1994, p. 28; Smelser and Swedberg 1994, p. 3; Portes 1995, p. 3). Financial markets, however, are primarily concerned with neither the production of goods nor their distribution to clients, but with trade-the trading of currencies and financial instruments not designed for consumption. When studying markets, sociologists have predominantly focused on producer markets, taking the firm as a point of departure-in line with both the distinctive role production has played in the discipline's understanding of capitalism and the focus early economic sociologists placed on the internal workings of organizations (Swedberg 1991; Baron and Hannan 1994; Carruthers and Uzzi 2000, p. 486; for an alternative approach, see Baker [1981, 1984]). The dominant line of research specializes in the analysis of interorganizational relations, in effect joining organizational analysis and market analysis through the use of network approaches that inspiringly analyze the nature of the relationships and networks and how these affect labor, product, credit, and investment (e.g., White 1981a, 1981b, 1993; Burt 1983; Baker 1990; Baker, Faulkner, and Fisher 1998; DiMaggio and Louch 1998; Uzzi 1997, 1999). As is characteristic of such research, the aforementioned studies gloss over distinctions between markets, in an effort to theoretically specify how social embeddedness operates; while these studies do not reject cultural differences between markets, they also are not designed to capture the types and patterns of social structural and cultural variation that a multiple-market model (Zelizer 1988; see also Mirowski 2002, chap. 8) suggests. Yet differences between markets are consequential at almost every level of the analysis of markets. The foreign-exchange market in particular is dominated by short-term spot transactions, the buying and selling of currencies, rather than complex financial instruments. No production effort on the bank's part is involved in regard to these currencies; when options, futures, and other derivative securities are traded, their 
value is calculated on the spot by traders themselves without recourse to production facilities. A large part of foreign exchange dealing is "speculation"-that is, the trading of assets with a view to gains from price changes and price differences. ${ }^{9}$ This also distinguishes foreign-exchange dealing from merchandise and services trading, which is oriented toward the transportation of goods from one location to another and their subsequent consumption at the end of a trading chain. Like other financial market transactions, foreign exchange transactions are second-order trading arrangements related to the first-order economy only very indirectly, through the profits that they generate or the effects that they have on the value of currencies. To mark the character of these arrangements as pure, or nonintermediary, trading cultures, we call them "cambist" markets.

A number of further characteristics that are linked to the specific cambist focus of these markets and its institutional implementation have significant implications for research: First, the specificity of cambist activities and their separation from primary economic activities manifests itself in the distinctive institutional arrangements and agencies they involve. Trading floors tend to belong formally to large corporations (e.g., investment banks), but they are at the same time separated from other corporate activities in terms of their goals, location, restricted access, distinct forms of governance, and so on. In a sense, the lack of a production function corresponds to a loss of significance of the organization as a mode of coordination and a complex arrangement of internal transaction environments (see also Williamson 1981; Coase 1937). We can view these units as institutional hybrids that are placed at the boundary between organizations and markets and that combine principles of both. For example, they are half steps between the firm and the market in regard to traders' part-employee/part-entrepreneur pay structure, their market-specific membership categorization and behavior, and the overall structure of the face-to-screen setting of such trading floors as a boundary-marking and boundary-traversing environment (see the section on a global orientation to a common object). Accordingly, cambist markets require attention to the role of individual traders, whose social role is absent in producer markets but who are the key operators in foreign-exchange markets. As market makers, traders take their own positions in the market in trying to profit from price differences while also offering trades to other market

\footnotetext{
${ }^{9}$ Historically, foreign exchange dealers were intermediaries in international trade; they provided services for importers, exporters, and others who needed foreign currencies to pay bills and buy goods. Today, only a tiny percentage of the current daily trading volume reflects real requirements of companies. The daily volume of dollar transactions in this market is approximately 200 times larger than the added volume of U.S. merchandise imports and exports, plus other sales that require foreign exchange (Caves, Frankel, and Jones 1999 , p. 420 ).
} 
participants, thereby providing liquidity for the market and sustaining it - if necessary against their own position (see also Baker 1984, p. 779; Abolafia 1996b, pp. 2-4). In other words, as a social form, these markets depend on custodians who revive them when they break down-who fulfill bridging and liquefying functions when activity streams start to gel, gaps arise, and the fluidity and continuity of the whole is threatened. Although the traders' losses and the volume of currencies that they can trade are limited by banks, traders are not constrained by any of the bank's views on the development of currencies but instead develop their own views on the currency that they trade (see also Goodhart 1988, p. 456). The shift in agency from the firm to the trader that this implies manifests itself in banks' readiness to move their trading operations to global cities that are the world's financial, but not production, centers (Sassen 2001; Strange 1988; Budd and Whimster 1992; Leishon and Thrift 1997), in search of pools of competent actors (i.e., traders) who can provide this agency. Sociologically speaking, individual traders also provide for the market's existence and process continuity through the intensity of their communication with one another, which we begin to characterize in this article. The phenomenon that transactions are performed through and instantiated in communication, previously noted from a microsociological perspective, is important here from the perspective of economic sociology: what must be recognized is that the markets studied take the form of a large, globally distributed conversation. In this conversation, deal making, information exchange, and personal talk come together on one platform, with information exchanges and personal talk also filling gaps between economic transactions and supplying the background for deals that are made via electronic brokerage. Thus, the ongoing conversation provides the market with social liquidity, which serves the market's economic liquidity. The relative ease and speed of communication would seem to be a sustaining factor in the relative ease and speed of currency transactions. In methodological terms, when attempting to characterize these markets, one has to pick one's way through the various manifestations of this conversation-rather than study production chains in organizations.

Second, an aspect of the conversational realization of these markets that deserves special attention is the exchange of knowledge and information. When Harrison White argued that markets are self-reproducing structures in which the key variable is that participants "watch each other within a market," rather than watch consumers (1981b, p. 518), he pointed to the gathering of information as an important part of producer markets. Economists assume a close link between financial markets and knowledge and information. This link emerges from the view that knowledge is contained in and extractable from asset prices (Fisher 1907, 1930; Hayek 
$1945)$ or that the latent function of capital markets is to provide information for decision making (Bodie and Merton 1995, p. 197). To conceptualize the importance of knowledge in this area, we can build on these ideas. The information contained in prices, for example, not only helps dealers make decisions but also stimulates deals. In other words, the information that arrives with price changes continually excites the system into further trading. Thus, the speculative exuberance (Shiller 2000, p. 3) and the volatility that are characteristic of cambist markets (as opposed to producer markets or intermediary trading) appear to be intrinsically connected to the fast flow of information. In addition, contentwise, the vast majority of market exchanges that are not pure dealing sequences involve knowledge and information. In other words, social liquidity is contingent on knowledge and information being traded among participants; knowledge appears to be the medium of relationships in global fields. Last, the knowledge flows map the world in which traders move; these flows constitute the special life world of a global social form that has "disembedded," left behind its natural embeddedness in local and physical settings. We argue that market reality itself is knowledge generated, that is, has no existence independent from the informational presentation of the market on screen that is provided by news agencies, analysts, and traders themselves. Although here we can only briefly illustrate the commerce of knowledge that flows through traders' interactions, the wider nexus of economic, social, and life-world functions of knowledge in this area should be noted and further studied.

Third, from an economic-sociology perspective, the markets studied have an inherently transnational character, by involving the exchange of national currencies and acting as external observers and evaluators of national macroeconomic policies that are signaled in exchange rates. These markets also have a specific global social form, which we can characterize by distinguishing between a global inclusive system and a global exclusive system. A globally inclusive financial marketplace is one in which individual investors in any country are able to freely trade shares across national boundaries. Such systems are in the process of being created, but they are far from being in place on a worldwide basis. The global social form evident in institutional currency trading is not based on either the penetration of countries or individual behavior, but instead is based on the establishment of trading bridgeheads in the financial hubs of three major time zones-that is, New York, London, and Tokyo-and perhaps in Zurich, Frankfurt, or Singapore as well (Sassen 2001, chap. 7). These centers cover the world by representing the time zones: they provide trading opportunities for banks and institutional investors in the three major continents of predominant interest to financial-service industries 
American Journal of Sociology

(the United States, Southeast Asia, and Europe) during their particular working times.

\section{ETHNOGRAPHIC FIELD RESEARCH}

To access this global exclusive system, we conducted field research on the trading floors of globally operating investment banks. Given the lack of sociological research on global institutional interbank trading, field research provided the empirical basis for the description of the form of the respective social actions involved. It also revealed the microstructural basis of the global social system of trading, its knowledge embeddedness, and the meaning of globalism. Our presence and participation in the field yielded richer materials and permitted a more refined analysis than would have been possible by use of standardized interview tools; however, the number and location of trading floors investigated may diminish generalizability. ${ }^{10}$ Field research consisted of a combination of participant and nonparticipant observation on floors, ethnographic interviews, and analysis of trading transcripts and other trading-related documents collected in the field.

We conducted field research on the trading floors of three globally operating investment banks in Zurich, where they are officially based. We selected two of the three largest Swiss banks and one private bank, each of which represents a different market segment. The first and largest bank, which we designate as "GB1," represents top-tier foreign-exchange trading among the world's largest securities firms; GB1 has continuously been ranked one of either the top 5 or the top 10 most profitable banks world wide in terms of reported foreign-exchange trading revenues or market share over recent years (FX Week 1998, p. 4; Euromoney 2000, p. 52). The second bank, which we designate "GB2," represents second-tier trading in terms of deal volume and size, with total revenue of approximately $\$ 700$ million in 1999 and with rising revenue from trading operations; this bank was selected because, in contrast to GB1 and other large investment banks, it offers 24 -hour trading services for the different time zones at the Zurich location, featuring, besides staff composing the Zurich daytime shift, an afternoon New York shift and an overnight Tokyo shift.

\footnotetext{
${ }^{10}$ In particular, we interviewed traders who had recently moved or traveled, asking them about differences among trading floors and trading practices, and we received the answer that differences reside particularly in such aspects as working hours, local knowledge, and the trading volume in local currencies. Trading practices and technologies were described as practically identical among trading floors. The present study is in the process of being extended to stock markets and global cities to learn more about generalizability.
} 
The third bank is a private bank that caters only to institutional investors and specializes in investment management and financial analysis. Data collection at this bank has so far been limited to these areas of operation. Research focused on the largest of the three banks, GB1, which is one of the world's leading securities firms in terms of financial resources, with approximately $\$ 9.8$ billion in revenues in $1999 . "$ In December 2000 , the bank reported a staff of more than 15,000 employees working in 56 offices across 37 countries and six continents. Interbank foreign-exchange activities have been concentrated in four financial centers worldwide: New York, London, Zurich, and Tokyo.

Institutional investors in these regions of the world are linked with GB1 (and other banks) through open, or immediate-access, phone lines. GB1's relevant centers and facilities are also connected through elaborate intranets-that is, internal computer systems within the bank that extend across the globe. The intranets include electronic information and brokerage services provided exclusively for institutional customers by firms such as Reuters, Bloomberg, and Telerate. Foreign-exchange deals through intranets start at several hundred thousand dollars per transaction and exceed $\$ 100$ million. Deals are made by investors, speculators, financial managers, central bankers, and others who want to avert or hedge against adverse currency moves, who want to profit from expected currency moves, or who need specific currencies to help them enter or exit transnational investments. Dealer-to-dealer contacts are made via the Reuters conversational system, which Reuters offers to institutional subscribers. ${ }^{12}$ Traders may also order deals through the voice broker (the voice of a broker via an intercom) or electronic broker (EBS), an automated dealing service that sorts orders according to best bids and offers, while they are at the same time engaged in dealing or information conversations.

Here we focus on spot trading, the direct exchange of currencies on the spot, which is the fastest dealing exchange. Spot trading involves an enormous volume of very-short-term position taking (buying and selling of currencies) and intraday adjustment of positions by traders. We also

\footnotetext{
${ }^{11}$ The profiles of leading foreign exchange banks can be inspected by consulting http://www.fxall.com/. Besides the revenues indicated, GB1 reported $\$ 7.8$ billion in equity and $\$ 275$ billion in assets as of December 31,1999 .

${ }^{12}$ Traders can be involved in up to four dealing and information conversations simultaneously. Incoming dealing requests are announced by a beeping sound and appear in a window at the side of the screen, where all traders who deal in the same instrument or currency can see the code of the counterparty and the request. Traders are matched with currencies: they handle only one currency pair for all major currencies. Several senior and junior traders may cooperate in responding to requests when trading volume is high and when calls arrive simultaneously or in short succession.
} 


\section{American Journal of Sociology}

observed the trading of options, which are the rights to buy or sell something at a specified price in the future. Option trades take more time to complete (i.e., minutes, instead of fractions of seconds) and involve thinking in multiples of months (i.e., in terms of the expiration dates of options). The spot market is a much broader, more liquid, and lower-transactioncost market than the option market (Goodhart 1988, p. 457).

The data collected at GB1 permitted a triangulation of ethnographic observation, interviews, and trading conversations. First, the data derive from 12 months of participant observation that was conducted at GB1 in 1996 by one of the authors of this article (Urs Bruegger), who is a former trader; during this time, Bruegger participated in tradingfloor activities $60 \%$ of the time (see also Bruegger 1999). Participantobservation data were supplemented by 12 periods of joint nonparticipant observation by both authors beginning in May 1997 and amounting to 36 full days of observation to date (the study is still ongoing). When traders were at their desks, we observed and recorded them rapidly making deals, adjusting their financial position, and engaging in information exchanges; we also observed morning meetings in which analysts on the trading floor and analysts speaking from London presented their forecasts, and we observed the opening and closing periods of trading. Second, two-thirds of the approximately 40 spot and option traders and sales people at GB1 were repeatedly interviewed (on an annual basis between May 1997 and December 2000) on the trading floor of the bank, providing 90 one-anda-half-hour tapes of qualitative interviews. ${ }^{13}$ Interviewees were selected to represent all major currency pairs at GB1 and GB2 (see below) and to represent only fully trained dealers with at least one year of experience in trading. Salespeople and analysts were included because of their cooperation with traders. Third, we collected a vast number of transcripts of dealing conversations and information exchanges among traders, of which 100 were randomly selected and analyzed; these are automatically produced records banks collect of all ongoing electronic transactions. Transcripts were divided into the following categories: pure dealing sequences, dealing sequences involving information exchanges, pure information/personal exchanges, and conversations marked for their normative content. Dealing transcripts are confidential, and permission to collect them was at all times at the discretion of the participants. As a consequence, they were highly valuable to us; the disadvantage is that it was not possible to collect representative samples of all conversations made

\footnotetext{
${ }^{13}$ Of the recordings made, 62 were with spot and option traders; 6 were with salespeople; 14 were with the heads of spot and option trading and sales, specifically about questions of supervisory work and trading and sales management; and 8 were with four analysts working on the trading floor and advising traders and customers.
} 
or to choose the interactions selected for illustration from random periods of a day, year, or market cycle. In the transcripts collected, dealing exchanges clearly dominate; field research suggests that dealing sequences involving information exchanges are common and that pure information exchanges dominate during opening and closing periods and when trading is slow. No indication can be given about the frequency of normative sequences in trading-floor conversations.

Data from GB2 served as a control to the data from GB1. In total, seven one-and-a-half-hour tapes of ethnographic interviews with the head of spot transactions, at trading desks and with the dollar-Swiss franc dealer, were recorded, during the 2000-2001 period; in addition, observations were made, and conversational transcripts were collected during the same period. No differences from GB1-with regard to the trading systems used (EBS and Reuters), the structure of dealing conversations, the face-to-screen setting, the orientation to the market, and other results described in this article-were discerned. This corresponds to traders' assertions that trading floors within the global circuit of high-volume trading institutions are identical, thereby making it possible for traders to fly from one city to another and immediately start trading there. Data from the third private bank served mainly to validate and extend our understanding of the knowledge embeddedness of. global trading.

With one exception, all traders, chief traders, and salespeople observed and interviewed were male, and all but one analyst was male; of all these, their ages ranged from 20 to 45 years. Retired chief traders' ages ranged from 55 to 85 years. The typical trading career consisted of starting as a bank apprentice and getting drawn into trading-floor activities between the ages of 19 and 25 years, in response to personal inclinations or needs arising in the bank. In contrast, all analysts and some salespeople held university degrees. On the floor, traders are trained on the job, starting as juniors, who act as assistants to experienced traders; if successful, they move on to senior trading positions. No trader was older than 33 years of age. Typical career patterns for aging traders consisted of going into sales, proprietary trading (speculative trading for the bank's account), or asset management, or moving on to management positions or leaving the market. We are not aware of any statistics that survey the international population of financial market traders or their career patterns. The professional traders association, ACI-the Financial Markets Association (formerly known as Association Cambiste Internationale) - has many national chapters, but its membership does not reflect the active trading population. 


\section{THE POSSIBILITY OF A GLOBAL WE RELATION}

A test case for the idea of global microstructures is whether microsociological concepts allow us to go beyond the notion of relational or network connectedness between firms in understanding markets as social systems. This is particularly relevant to global markets, in which adjustment must be made to compensate for the geographic distance between participants. Microsociologists have used the concept of intersubjectivity to characterize social binding. Hegel's dialogical notion of self-awareness, in which consciousness of self derives from recognition granted by the other, can be seen as a formulation of intersubjectivity (Wiley 1994, p. 76), as can Mead's notion of role-taking (1934, p. 80 ) and Blumer's concept of situational negotiations, which embody the interactional and emergent qualities of social reality (Blumer 1967; Collins 1988, p. 381). As these examples show, ideas about intersubjectivity are pitched at a fundamental level of social relatedness. There is also a tendency to assume that intersubjectivity arises in situations that are highly focused in a small space, whether it is the individual's mind or the slightly larger context of face-to-face interaction. Can we maintain that a level of intersubjectivity also obtains between individuals who are globally dispersed in space? What passes between territorially separated individuals who may never share the same space on the level of consciousness, interpretation, or reciprocal orientation? Markets-in particular, spot markets-are purportedly classic examples of anonymous, discrete exchanges ruled by supply-and-demand adjustments, rather than intersubjectivity. In general, markets have been contrasted with more genuine forms of social organization by their lack of planned coordination, reciprocity, and governance structure (Williamson 1975, 1985; Powell 1990). Can we nonetheless assume that a certain level of intersubjectivity is characteristic of some markets? In this section, we submit that participants' reciprocal observation of markets on screens-combined with temporal mechanisms-may constitute a basis for both a form of intersubjectivity and the integration of some global spheres. We will discuss this by elaborating on Schutz's idea of a we relation, with which he attempted to circumscribe intersubjectivity, as arising in the face-to-face situation (e.g., 1964, pp. 25-26). Although Schutz's concepts were conceived for bodily copresent participants, he turned the spotlight from the subject as actor and to the subject as observer of a mediating object; he also emphasized the temporal immediacy and coordination of observation. These ideas are the ones from which we can gain analytic leverage in the dissection of global fields. The global markets studied are arguably communities of time, with their identities based on interlocking time dimensions and the observation of a common object (i.e., the on-screen market). We will also show how institutional 
arrangements contribute to and extend the intersubjectivity and the integration that can be derived from Schutz's concepts.

\section{Schutz's Concepts}

To summarize Schutz's thinking, we begin with what passes between two individuals who are facing each other:

In the face-to-face situation, the conscious life of my fellow man becomes accessible to me by a maximum of vivid indications. Since he is confronting me in person, the range of symptoms by which I apprehend his consciousness includes much more than what he is communicating to me purposefully. I observe his movements, gestures, and facial expressions, I hear the intonation and the rhythm of his utterances. Each phase of my consciousness is coordinated with a phase of my partner's. (Schutz 1964, p. 29)

In this passage and others, Schutz highlights the role that nonverbal occurrences play in making another person's presence and consciousness accessible as the background for overt interaction. The question of how and why action occurs is excluded, to focus on the prior question of how and why a more primordial form of sociality arises from the reciprocal orientation of participants toward one another (Schutz 1964, pp. 27-33; Natanson 1962, p. 13). To characterize this orientation, which he saw as a unique feature of face-to-face situations, Schutz very vividly described the "interlocking of the glances" and the "thousand-faceted mirroring of each other" (1967, pp. 169-70). Meaning, in Schutz's accounts, no longer resides in the actors' minds (in their intentions) but is relocated in the observers' minds (see also Campbell 1996, pp. 43-46) and is, in fact, contextually determined and manifested.

In trying to explicate intersubjectivity further, Schutz extended his views of the individual as an observer. As an example, he describes two subjects watching a third object, a bird flying, rather than two individuals facing each other. In analyzing this situation, Schutz arrived at another central idea, temporal coordination. In Zaner's assessment (e.g., 1964), the reciprocal interlocking of the time dimension is for Schutz the core phenomenon of intersubjectivity. Why did Schutz associate intersubjectivity with time, which is a connection not commonly made in sociology? Schutz's ideas were based on objects observed to move or change over time. The experience of such events is temporal, in that it is constituted step by step as each event unfolds. Two persons watching the same event are brought into a "state of intersubjectivity" by their experience evidently changing in similar ways, in response to what unfolds. The basis of this sort of we experience, for Schutz, was the temporal immediacy of events. Temporal immediacy allows one to recognize and follow another 


\section{American Journal of Sociology}

person's experience of the third object as contemporaneous with one's own experience.

Schutz attempted a number of formulations of temporal coordination, always associating it with sequential aspect of consciousness, rather than with any content. He spoke of the coordination of "phases of consciousness" and the "synchronization of two interior streams of duration" and said that, during this synchronization, "we are growing older together" (1964, pp. 24-26). For us, the point is that, in emphasizing temporal coordination, Schutz departed from any attempt to base social relatedness on the assumption of the shared content of experience or on any real understanding of other minds. Instead, he left the subject recognizing the other as a fellow human being here and now, evidently paying attention to the same event. What turned this experience into a we relation, according to Schutz, was the contemporaneousness of an event, the subject's experience of it, and the indications of the other's attentiveness to it: "Since we are growing older together during the flight of the bird, and since I have evidence, in my own observations, that you were paying attention to the same event, I may say that we saw a bird in flight" $(1964$, p. 25$)$.

It is both his avoidance of any requirement of real understanding and his shift from two subjects engaged with each other to subjects engaged with a third object who notice this engagement that makes Schutz's ideas useful for the conceptualization of the sociality of global fields-as a level of intersubjectivity and integration that obtains before any concrete relationship is entered into and before any economic transaction has been performed. In basing his we relationship in a community of time and putting aside the question of understanding other minds, Schutz did not, however, also put spatial immediacy aside. For Schutz, sharing the same segment of time implied the genuine simultaneity of participants' streams of consciousness only if they shared a common space-the space that afforded them the possibility of partaking in the "step-by-step constitution" of experience of an unfolding event (Schutz 1964, p. 34). Schutz evidently made no distinction between spatial immediacy and the possibility of paying attention to the same event. This distinction is, however, a crucial one when events mediated by electronic transmissions can be witnessed in real time worldwide without participants' sharing of a common space. Another related problem with Schutz's notions is that he underestimated processes of verbal or visual formulation (i.e., processes of explicit communication) as conduits of intersubjectivity when more parties are involved and when the object is complex. Even in the faceto-face situation, it should be easier to achieve a sense of intersubjectivity when the parties cry out what they see-as they do, for example, on trading floors. Schutz seems, however, to have considered silent situations to be more fundamental and even analyzed situations in which talk was 
forbidden, as is the case when listening to a musical performance (1964, pp. 159-78). A further problem is that Schutz paid little attention to elements of deliberateness and of the contingent accomplishment of intersubjectivity, although such elements are clearly implicated in, for example, a musical performance. These elements should, however, be recognized and may acquire greater relevance in dispersed global fields.

\section{A Global Orientation to a Common Object}

To illustrate global orientation in financial markets, we address the three elements that are central to intersubjectivity: (1) participants' orientation toward and observation of a common object, (2) the reciprocity of these orientations, and (3) interlocking time dimensions. How is the orientation toward a common object instantiated in global trading that is spatially dispersed across all time zones? A key concept here is that of the faceto-screen situation, as opposed to the face-to-face situation. Traders work from trading floors located in banks in what are ostensibly face-to-face situations in which they are seated close together to be able to observe one another and feel the mood of other traders. Nonetheless, traders are not in a traditional face-to-face situation. Traders do not face one another but face their screens, an arrangement that transforms the face-to-face situation into, literally, a back-to-back situation. This arrangement implements a split in orientation in the interaction order, forcing, on the one hand, an orientation toward the screen that links the physically present person with a global sphere and, on the other hand, a secondary orientation to the local setting and the physically present others participating in it. We can distinguish here between the living presence of the trading floor, with its possibilities for immediate rapport, and the engrossing presence of the screen and the global sphere. Traders maintain their double orientation through a division of labor between the senses. The screen-and, through the screen, the global sphere of transactions-is what is dominant; the screen grips the traders' visual attention-in a way that signals not only an orientation toward this sphere but also the intense observation of its changing features. At the same time, traders tune in to the trading floor (i.e., the local sphere) through the auditory channel, overhearing others' "response cries" (Goffman 1981, pp. 78-80), shouted questions, and oral conversations. The split in orientation in the interaction order exemplifies what Giddens (1990) calls the disembedding of the global from the local as a process that works, on one level, through actors' bodies - through a sensory-specific segmentation of their awareness sustained by material configurations (e.g., that of the room)-and, on another level, through institutional arrangements that instantiate trading floors as part-market/part-organization settings. One example of the 
latter type of arrangement is the bonus system of pay, in which traders receive, in addition to a basic salary, a yearly bonus that is often several times as large, depending on the amount of money made for the bank. Traders may also have investments of their own and manage them while doing their work for the bank. On the one hand, the basic salary epitomizes the trader's employee status, that is, his dependence on the bank for his livelihood, resources, and institutional identity. On the other hand, the yearly bonus (as well as private investments) indicates that the trader is an independent entrepreneur whose financial well-being depends on personal success in the global market; as Abolafia (1998, p. 72) has shown, traders feel themselves to be such entrepreneurs. Split pay arrangements are of course also used in other sectors of the economy to increase motivation and competition, but, in the present example, the membership categorization that accompanies the split pay is notable. There is a domain "out there" to which traders belong, as market participants and market makers; traders want to be connected and want to keep track of this domain. When traders leave their job and are no longer connected, they may feel that they have been stripped of part of their selves-and may buy little handheld Reuters screens to reconnect themselves, however tenuously.

We can now answer the question of what the same events may be that could plausibly be construed as globally observed in the same binding fashion in which events are observed in the face-to-face situation. The third object (i.e., the bird) that traders watch together around the clock is the market, as it is assembled in identical (price actions, market analyses, news descriptions, etc., furnished by global information providers), overlapping (information exchanged through personal relationships), and coordinated (in the many windows and channels of the screen with which participants interact) fashions. On each of these screens, the same market has a vigorous presence; traders worldwide who deal in the same financial instrument watch the same screen content, which is delivered to them by globally operating firms, such as Reuters, Bloomberg, and Telerate, and by the banks themselves. These firms provide the interconnected work stations and the information, dealing, and accounting capabilities the global system needs. The screen gives a gestural face to the signals that are transmitted through this information technology; it instantiates the market as a life-form that inhabits the technology (Knorr Cetina and Bruegger 2002a, 2002b).

\section{Reciprocity as a Requirement of Intersubjectivity}

The proposed face-to-screen concept replaces the face-to-face concept in the response-presence-based situations that we are studying-that is, it 
captures the orientation of participants toward the global sphere that is present on screen. The screen itself is like a mirror that reflects market participants' activities to one another in real time, at the same time that it enables these activities to happen. Here we encounter Schutz's second requirement of intersubjectivity - the reciprocity of orientations. For Schutz, observing the other observe was crucial for any interlocking of subjectivities to be achieved; his emphasis was on nonverbal expressions as signals of the other's attention to the situation. It is a characteristic of the global fields studied that, on one level, the observation of other traders observing is not necessary to convince oneself of the attentiveness of others to the same events. On all trading floors we visited, traders-and heads of trading as well-spent most of their time at dealing desks monitoring market events; heads of trading also monitored traders' activities and their attention signals. As they take positions (i.e., as they buy and sell currencies for their own accounts), traders become part of the market, and, as a consequence, market events in general and their own position within them is of intense interest to them. Thus, on one level, the reciprocity of observation is an essential and invariable aspect of these temporally focused global interaction systems, in addition to being an underlying source of intersubjectivity.

On a second level, however, traders want to learn about others' concrete involvements in the market, which change continually and are signaled on screen. What are these signals? They are the deal requests that counterparties make, the messages that others send, and the price movements that they trigger. Through these signals, absent market participants have what Goodwin (1995, p. 260) once called a mediated presence on screen. A significant part of traders' observational activity goes toward the identification and reading of the signals of mediated presence with a view to market players' possible moves and intentions. Another significant part goes toward the conveyance of what they observe to other market players with whom they maintain relationships. In this sense, traders transmit and amplify the signals of reciprocity, thereby contributing to their spread. The following example of this is taken from a trading conversation that we will discuss in more detail later; in the exchange, a trader at GB1 ${ }^{14}$ tells his counterpart at a global securities house that the Zurich trading

\footnotetext{
${ }^{14}$ Throughout, we refer to global investment banks and other globally operating banks as GBs (for specific designations, see the section titled "Ethnographic Research"), in accordance with banking confidentiality requirements; however, we do indicate the trading location (e.g., "NY" for New York). Names of individual traders, salespersons, or managers have been deleted. Where trader initials occur in transcripts, we have abbreviated the initials and indicated the type of dealer (e.g., "InSD," which stands for initials, spot dealer). Changes made to preserve confidentiality are indicated by angle brackets.
} 
floor is buying a rather large sum ("AROUND 150 MI[LLION]") of German marks ("DM") against Swiss francs ("SFR") that he believes the rate will not go higher ("LOOKS DAMN TOPP[IS]H HERE"), and that another Swiss bank (here designated as "GB4") is selling the German marks ("THINKING <GB4>"):

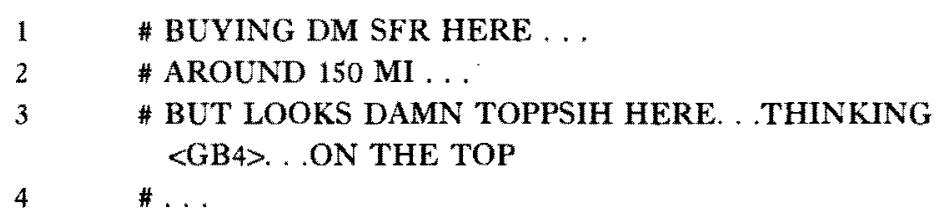

It is important to note that reciprocity here acquires an accomplished sense; by acting as conduits of information, traders and salespeople enable others to see what it is that they see market participants doing, and they help them infer what these parties may observe in the market. More reciprocity is accomplished through internal bulletin boards, which were progressively implemented by GB1 and other banks for specific financial instruments (e.g., spot or option trading) from 1996-97 onward. Internal bulletin boards allowed the dealers in this instrument to post what they saw in their local environments and to list some deals, so that others in the bank could pay attention to them. The following sample entries report what various banks, including a central bank, (BDF stands for Banque de France, and SNB stands for Swiss National Bank) are doing, followed by a trader reporting a deal (in Swiss francs ["CHF"]) he made for a Scandinavian proprietary desk; omitted are longer rate and morning meeting reports and technical updates from Singapore, London, and Zurich between 4:42 A.M. and 7:02 A.M.:

[Tokyo; 2:24 A.M.] Hearing a rumour that BDF is already in the market.

[Singapore; 3:29 A.M.] had problems with bulletin board earlier.

we bought usd 50 mio agst sf at 1.3895 for german bank.

[Zurich; 7:02 A.M.] SNB IN 1M CHF OVER TODAY AT 1 1/4 PCT VERY AGRESSIVE

[London; 7:19 A.M.] Bought 50 demchf for scandi prop. desk.

Bulletin boards, like the information exchanges illustrated before, enhance the transparency of the system within particular circuits. One can see them as part of the observatory system that the screen represents, that is, a system that allows participants to partake more directly in the stepby-step constitution of a dispersed market by giving them glimpses of the activities of concrete buyers and sellers from a distance. These activities 
mark the current context as also involving what Schutz called the "interlocking of motives characteristic of interaction in the we-relation" (1964, p. 55) -in other words, the possibility of the subject's "in-order-to" motive becoming other's "because" motive. A trader selling a currency in order to take a profit may trigger trading responses in others because of what he or she has done. Even if no direct response is triggered, the signals of others' involvements continually shape market participants' strategies and attitudes. Some market makers also reflexively use the signaling potential of deals to try and influence the market, that is, price movements and other traders (see also Soros 1994). In all these cases, the reciprocity indicates that global financial markets are fields of interaction: at any point in time, all traders will be watching the same events and one another, but some also interact (trade) and, in doing so, implement a new level of signaling and responsiveness among themselves.

Schutz's interlocking of subjectivities can also be related to a third kind of reciprocity, which plays an important role in dealers' behavior. As market makers, traders are expected, within limits, to offer deals to other traders who make price requests, even if the deal runs against their current financial interests, to reciprocate for others' willingness to deal in their turn. As a generalized principle, dealing reciprocity displays the market as a place where solidarity in a common goal, that of sustaining the market, can be expected-with the role of market maker designed to perform the sustaining function. The normative sense of this reciprocity can be gleaned from the following excerpt of a dealing conversation that is reprinted in full, as an example, in the International Traders' Association Code of Conduct (Association Cambiste Internationale 1996, p. 59). In the transaction, a 10-million-Swiss-franc currency option deal had just been completed between two traders, when the caller (lines indented) asked whether the seller of the option (lines marked by "\#") had anything to offer in 3 million German marks ("3 M DEM"). The answer is negative ("Sorry ntg there friend"), whereupon the caller complains about the lack of reciprocity in this response ("srry???????? ever heard from reciprocity ????????") and threatens to cancel the previous deal ("? if u won't quote I will cancel previous deal"). The dealer who was called confirms after a moment ("Mom") that he cannot offer anything in German marks and accepts the cancellation of the previous deal ("Really sorry but ntg in DEM for the mom so noth. done in CHF frnds"), whereupon the caller retaliates by declaring the business relationship between them to be finished:

OK tks anything in $3 \mathrm{M} \mathrm{DEM}$

\# Sorry ntg there friend srry??????? ever heard from 


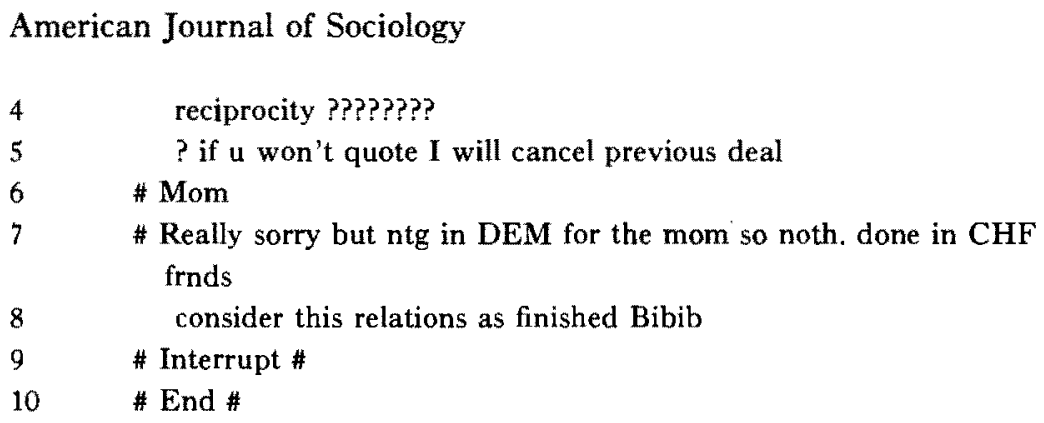

\section{Global Markets as Communities of Time}

We will return to dealing conversations and the structural use of interaction to enforce order shortly. First, though, one further aspect of intersubjectivity, temporal coordination, needs to be given special attention. In Schutz's scheme, temporal coordination is the basis for both the reciprocity of observations and the joint orientation to a common object in the face-to-face situation. Temporal coordination, one assumes, must play an even bigger role in the absence of spatial immediacy, if a phenomenon such as intersubjectivity is to obtain. Temporal coordination is indeed more elaborate and intricate in the global markets studied than in any context envisioned by Schutz. These markets are communities of time, and it is this condition that is central to their historical distinctiveness as social systems that overcome the geographic separation between participants. To turn the argument around, we assert that intersubjectivity could not be a characteristic of spatially dispersed markets if temporal integration were absent.

What do we mean by a community of time? First, traders, salespeople, and others on trading floors located within a particular time zone watch the market as it enters their view in the morning and builds up during the day virtually continuously in synchronicity and immediacy during working (and waking) hours. ${ }^{15}$ All three aspects of temporal coordination are important here: synchronicity is present in traders' and salespeople's

\footnotetext{
${ }^{15}$ As Harvey has argued (1989, pp. 239-59), increasing time compression is a characteristic of the whole process of modernity and of postindustrialization. A similar argument had been advanced by McLuhan (1964, p. 358), who proposed that electricity establishes a global network of communication that enables us to apprehend and experience media-transmitted events nearly simultaneously, as in a common central nervous system. To date, however, few media events are simultaneously transmitted across time zones, and media content is adapted to local cultures and locally reinterpreted. We argue that many other mechanisms and infrastructures-and in fact, a secondary economy of information collection and transmission-need to be established to create a global social form.
} 
observation of the same market events simultaneously during the same time period; continuity is present in traders' observation of the market virtually without interruption, having lunch at their desks and asking others to watch when they step out; and temporal immediacy is present in the immediate real time availability of market transactions and information to participants within the appropriate institutional trading networks. Local news is also transmitted live on screen when the events (e.g., announcements of economic indicators) are scheduled at a particular time, or they are transmitted with as little delay as possible. Traders, investors, and others attempt to gain advance knowledge of special developments, but these pursuits presuppose, rather than undercut, the community of time that obtains with respect to the market.

Second, time coordination involves a temporal division of labor across time zones, such that the community of time extends around the clock. As an example, take the trading instrument of an option to buy or sell a currency at a particular point in the future at an agreed price. In contrast to the instantaneously completed on-the-spot trades of currencies discussed so far, options expire weeks or months after the deal is made; hence, unlike a spot trader's accounts, an option trader's accounts cannot be closed every night. One way to globally organize such long-term transactions is for option traders at one desk to pass their option accounts every evening to the same bank's option traders at another desk in the next major time zone, who will manage the accounts and add deals during their working hours. The option book that circles the globe indicates global financial cooperation, extending the surveillance of Schutz's bird in flight, the market, through the eyes of others, when it threatens to disappear from view during the night. As a result, the coordination of consciousness that Schutz discussed becomes more inclusive, encompassing groups that are not simultaneously present but take sequential and overlapping turns observing and acting on the market; traders coordinate trading intentions and philosophies with the next and previous desks in evening and morning phone calls and electronic conversations, respectively, and the book remains on their mind (and available on their screens) while it is out of their hands. In other words, options traders, by passing the book around the globe, can be viewed as attempting to intertwine the consciousness of those attending to it in different time zones, by creating an around-the-clock synchronization of observation and experience.

Third, as an aspect of temporal community beyond this attempted global contemporaneousness, calendars and schedules-that is, dates and hours set for important economic announcements and for the release of periodically calculated economic indicators and data-structure and pace participants' awareness and anticipation. Calendars and schedules create an atmosphere of collective anticipation and preparation for specific 
events that pace and interrupt the regular flow of market activities. Temporal structures of this sort recurrently focus a global field of watchers (i.e., participants) on possible changes of direction of the third object (i.e., the market). They bind the field to specific time frames around which global attention is heightened and in relation to which expectations are created. The ordinary temporal flow of synchronous and sequential time-zone observation is thus punctuated regularly by potentially trendchanging occurrences. The scheduled character of these events not only synchronizes experience on a collective and global level but also adds to it a measure of periodic emotional arousal (see Zerubiavel 1981, pp. 65-68). Durkheim ([1983] 1964) thought such arousal was central to the creation of a feeling of solidarity; he assumed that the we experience arises when a group becomes excited. Thus, synchronized collective emotional arousal around weekly, monthly, and quarterly calendar events can plausibly be assumed to further enhance the integration of dispersed global groups. More integration results, presumably, from the additional narrative elaboration of these events. On an economic level, schedules create points of interface between the primary economy and secondary, cambist markets-that is, the data released at scheduled events describe the firstorder economy in terms of indicators of productivity, unemployment, and consumer confidence; indicate interest rate changes; and so on. Participants and analysts interpret the meaning of these events contained in stories that define a currency's long-term and short-term market prospects and situation in the context of the event (see also Mars 1998; Stark 1998). On a sociological level, the stories tie the field together by circulating through information relationships, news commentaries on screen, and televised discussions to which traders tune in. New data releases provide the opportunity for the reconsidering and changing of the narratives. Nevertheless, unscheduled events - ranging from natural disasters to political upheavals, as well as insider knowledge of possible developments (e.g., mergers and acquisitions, which often require huge sums of foreign money)-also shape the stories; these unscheduled events punctuate the flow and refocus global fields as well.

The complex temporal structuration and reciprocity that we have described give weight to the argument of a level of global intersubjectivity that extends beyond the face-to-face situation. The existence of such a level of connectedness provides a first substantiation and conceptual clarification of the idea of global microstructures. Before proceeding, we reiterate that what we have described has implications beyond Schutz's intersubjectivity and the face-to-face situation; our overall aim in this article is to express the meaning of microstructuration in a global setting. First, the idea of an interlocking time dimension depends both on the availability of interlocking trading technologies in all dealing positions 
and relevant trading floors and on companies that assume much of the appresentation function-that collect and supply what goes on elsewhere in geographical space and present it on screen more or less instantly. The screen is not just the equivalent of another person's face but is also a complex mirroring device that encapsulates these capabilities. Prior to the screen's introduction, traders could not simultaneously watch the market. In 1973, Reuters first launched a computerized foreign-exchange system called "Monitor," a generalized market observer, but this system provided mainly news and prices. Eight years later, Reuters launched a new system that went live in 1981 to 145 institutional subscribers in nine countries and was extended within a year to Hong Kong, Singapore, and the Middle East, resulting in a market with a worldwide presence (Read 1992, pp. 310-11). From that point onward, deals could be concluded on screen within two-four seconds, and dealers could communicate via the screen. Before the market went on screen worldwide, dealers spent most of their time determining where the market was-that is, determining who was willing to deal and at what price, a task accomplished via phone and telex. The market stayed in territorial space, hidden in transnational banking networks of institutions that neither shared the same news and dealing prices nor knew about all interests in dealing. Any coordination of consciousness that did obtain was limited to those moments and parties involved in particular connections. Today, the level of intersubjectivity discussed would obtain even in the absence of any such connections-for example, if deals were made exclusively via the EBS mentioned before and did not involve any of the conversational dealing and information relationships that we will discuss in the next section. Second, global intersubjectivity is based, at least in part, on what ethnomethodologists call formulations, that is, on explicit verbal statements of observed events and activities, as well as narrative interpretations of these events. Note that signs of a more gestural quality-for example, price changes or traders' emotional responses to the market that can be observed in dealing rooms-retain their importance. Third, as was implied before, global intersubjectivity has an accomplished sense; traders play an active role in the transmission and amplification of signals of market presence and reciprocity. Last, temporal synchronicity, continuity, and immediacy are elaborated by the invention of means (e.g., global books) of temporal coordination across time zones and by partitionings that result in markets' individual rhythms, calendars, and schedules. At least some of these structures result from institutional adaptations-for example, central banks' and statistical offices' willingness to play along (i.e., to make their decisions and report data at regular intervals, avoid leaks, and assure worldwide equal access to the information).

Where does this leave us from the point of view of economic sociology? 


\section{American Journal of Sociology}

First, what we have said reinforces the view that markets can be viewed as social systems: if we can claim that there is a level of intersubjectivity for global markets, then any view of these markets as atomistic exchanges plainly ignores much of what goes on. On a second level, the approach that we have chosen expands the understanding of how some markets are social systems. Since Granovetter's influential work (1985), embeddedness has been used to make sense of the social organization of the economy (see, e.g., Swedberg 1997, p. 162; Carruthers and Uzzi 2000, p. 487); research has focused on relational embeddedness-that is, the embeddedness of economic action in social networks and relationships-and structural embeddedness-that is, the interdependence of market exchanges and cultural, political, and social background institutions (Barber 1995; Portes 1995, p. 6). The intersubjectivity that we identified suggests a third type of social organization, defined by the interiorized characteristics of markets as they are performed in practice. One implication of the present research, with regard to embeddedness arguments, is that we need to distinguish between different forms of market coordination (see also Thévenot 2001) and to explain how they evolve and relate to each other. Presumably, pure relational or network forms of coordination and the reflexive, temporal form of coordination that we have described are two different things. Foreign-exchange markets before they were put on screen worldwide may have been primarily relational markets in which transactions were conducted in the bilateral mold; thus, they would have lacked the kind of intense temporal coordination and reflexive observation systems that we discern today. Contemporary foreign-exchange markets do not lack relational ties, as we shall see below, but these reinforce, rather than form, the basis of temporal coordination.

\section{GLOBAL CONVERSATIONS}

When markets were public marketplaces, they were surely also places of debate and communication. Some historians of finance have emphasized market talk with respect to how it reflects the rise of finance in literary texts, popular theater, and investment manuals in the 17 th and 18th centuries (Agnew 1986; Nicholson 1994; Preda 2001). One feature of electronic interbank trading is the renewed importance of conversation. First, conversations are not only about trading but also have moved to the heart of exchange; they are a means for global transaction performed via the Reuters conversational dealing system. Second, conversations are the means for information exchange between dealers on a worldwide basis; they carry the information that is most concrete and most directly relevant to the moment-to-moment buying and selling decisions. Third, dealing 
and, in particular, information conversations are the means for the building and maintaining of relationships in the electronic space of these markets (see "The Commerce of Knowledge," below). In this section, we shift the focus from issues of integration and toward a second level of patterning, the character of these markets as systems of communication, which the term "global microstructures" is also designed to capture. The appresentations described before and their temporal coordinates constitute the life world of collective systems that are generated entirely in a symbolic space; the dealing conversations on which we will focus demonstrate a way in which interaction (i.e., business) is conducted in this life world. We also discuss further normative aspects of the system that are enforced in dealing conversations and the bodily extension and anchoring of disembodied global interactions. Pure response-presence-based interactions do not exclude, but continue to evoke, the feelings of physical exposure and vulnerability that Goffman saw as characteristic of situations of bodily copresence. This is another sense in which global microstructures can be seen as extended beyond the face-to-face situation.

\section{Dealing Conversations}

The currency flows that circulate around the globe become initiated, energized, and partitioned when traders and others who are willing to make deals initiate conversations with one another. These are performed by typing and receiving messages on the screen. The following message illustrates the shortest and most common trading sequence, which takes just 20 seconds or less, as on the printouts that we obtained (with names erased and lines numbered; for details, see n. 6):

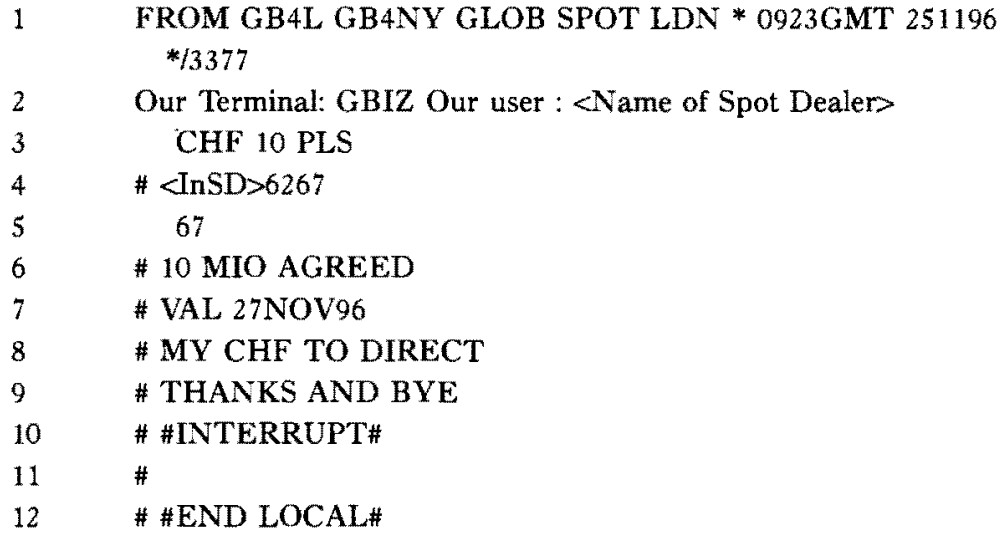

The interaction begins with an identification (lines 1 and 2), which 
appears on screen and tells the trader where the caller is located-that is, at the spot desk of another large and globally active bank (i.e., GB4) in London ("GB4L," "SPOT LDN")-and that currencies are traded directly, or on the spot. Also indicated are the date, the time, and an identification number, as well as the terminal in Zurich and the name of the trader there. The core of the trading exchange begins in line 3 , with an initiating question in which the London dealer asks for the price of 10 million U.S. dollars against Swiss francs, by typing "CHF," "10," and "PLS" (please). We call this a "challenge," in accordance with the interactional understanding of the initiation as a competitive, economic, and potentially aggressive move (see below). The Zurich trader, whose initials are given (here: initials, spot dealer), responds by typing endpoints of a price range, "62" and " 67 ," meaning that he is willing to buy U.S. dollars at a rate of 1.4062 Swiss francs per dollar and to sell them at a rate of 1.4067 Swiss francs per dollar. In economic-interaction terms, he enters into an engagement with the challenger by offering a commitment to the price range to which he and the challenger are bound. The London dealer then selects the deal: he indicates that he wants to buy dollars by typing the last two digits of the Zurich trader's selling price (" 67 "). Economically, the selection corresponds to a gain or loss on either side and to a corresponding repositioning of the parties in the market. The conversation concludes with a preprogrammed closing sequence that confirms the size of the deal, the date of the deal's settlement ("VAL27NOV96"), the account to which the Swiss francs should be paid ("MY CHF TO DIRECT," meaning GB1 Zurich), thanks, and a greeting. If the identification is included in the first term, then the sequential structure of global trading conversations corresponds to the pattern challenge-engagementrepositioning, or, in more neutral conversation analytic language, to an initiation-response-selection, followed by a closing sequence.

Dealing conversations are short but highly complex, hiding within them a multitude of global, institutional, and economic references. The global character of the conversation emerges from the language used, the identification sequence, and the exchange rate given in line 4 . All trading conversations are conducted in English; switching from the face-to-face situation to the face-to-screen situation entails switching to English, which is used on all trading floors worldwide. Second, the identification sequence (lines 1 and 2) indicates three global centers of trading: New York ("GB4NY"), London ("LDN"), and Zurich ("GB1Z"). The abbreviations "GB4NY," "GLOB," "SPOT," and "LDN" add a further detail, which is that the caller works in London but the global headquarters of the caller's global investment bank's spot trading is New York. A further indication of globality is the announcement of the Greenwich mean time (GMT) in line 1 (see Zerubiavel [1982, pp. 12-13], for the interesting historical origin 
of GMT). Since these markets spread across all time zones, time is fixed to a single place to assure global identification of the correct transaction date. Finally, a more hidden reference to the global character lies in the exchange rates of line 4 . The " 6267 " message globally sets the exchange rate for interbank dollar-Swiss franc trading on this day at this particular point in time. The deal at this rate constrains and, to some degree, selects the terms of the next trade of dollars against Swiss francs; market participants see the rate on the GB1 intranet or learn about it indirectly, from the electronic broker who indicates the price at which the last deal was made, and the market participants construe the next price according to this rate.

A second feature of the conversation is its institutional and economic character. As Drew and Heritage have argued, institutional talk typically involves more constraints than ordinary conversations-for example, constraints on goal orientations informing the talk, on allowable contributions, on inferential frameworks particular to specific contexts, and on the overall structural organization of talk (Drew and Heritage 1992, pp. 22-23, 43; Boden 1994). Here, some structural limitations of trading conversations result from being conducted within a specialized computerized turn-taking system that allows no overlaps and in which turns are formally passed on to another participant by pressing a key. The system provides interrupt keys, though, that force a change of turn and are used to gain time. More substantive institutional constraints emerge from the way that information is requested, delivered, and received. Such constraints were found, in the past, to be strongest in courtroom settings, in which participants orient their conduct by reference to legally enforceable rules. Here, convention and expedience, rather than legal constraints, appear to guide conversational form, and this is where the economic character of the transaction becomes more apparent-specifically, in the desire to perform deals swiftly, without cost in terms of time and money for oneself and others; transparently, oriented to the fact that deals are recorded and open to inspection by supervisors and others; and in a conflict-free manner, free of complex interpretative issues among counterparts. Economic expedience translates into minimalism; deals are basically performed in three turns (see lines 3 to 5 above), each specifying bare essentials: volume and kind of currency ("CHF 10 "), price ("6267"), and buy or sell request ("67"). There is typically no greeting at the beginning, although standards of politeness are maintained through "please" abbreviations, as well as "thank you's" and greetings at the end. There is variability; for example, the caller may respond equally well by indicating intent (e.g., "I BUY" or "BUY" or "MINE"), rather than the rate, and the abbreviation for Swiss francs also appears on some of our transcripts as "SFR" or even "SWISSI." There appears to be no variability, though, in standard se- 
quences with respect to a trader's price indication ("6267"), which is unhedged, is nonnegotiable, and normally is not accompanied by other words. The caller's buy or sell response, a central component of the trading conversation, is offered in equally unambiguous terms, cleared of other content.

Rules, Codes of Honor, and the Structural Use of Interaction Means to Maintain Order

The minimalism characteristic of trading conversations may count as one of their identifying details (Garfinkel et al. 1981); its economic basis lies in the global competition and the price volatility that make speed mandatory to the trader. More of the economic character of these conversations emerges in connection with a second characteristic of dealing conversations, that is, their embodiment of rules of conduct. Together with the conventions outlined, these are the mechanisms of social governance that form the lex mercatoria - the rules of trading practices and trading parties-of the system. A first set of rules is oriented toward the prevention of uninhibited profit seeking. For example, traders' initiating questions have to be uttered in a neutral way that does not disclose the caller's intent (i.e., to buy or to sell), to receive a fair price response; callers, unlike clients discussing options with a salesperson, presumably have formed such an intention. The responding trader is constrained to respond by indicating a price for both (buy and sell) options. Another important rule-and one whose violation will incur sanctions-is that traders commit themselves to the price that they indicate. They are bound to honor it even if they have made a mistake-as long as the caller's response comes within the understood time frame of approximately 2 seconds and as long as the trader has not regained the turn by an interrupt, to invalidate the price. A third rule of interest with regard to economic theory and auction, bazaar, and other markets where the price is negotiable (Smith 1990; Geertz 1978; DeLaPradelle 1995; Clark and Pinch 1995; see also Callon 1998, pp. 264-66), is that the price is nonnegotiable within a trading interaction; all a counterpart can do is forgo the trade and hope for a better price to be offered either at a later time or somewhere else. Conversationally, this means that there are no turns allowed that challenge a price range-other than a turn that ends the conversation prematurely, without a deal. Frequent premature endings, however, reflect back on the trading parties and their relationship, to which we will return below.

These institutionalized expectations are extended by an informal code of honor, ${ }^{16}$ by which traders are informally assessed and by which trading

${ }^{16}$ The ACI compiles a Code of Conduct that also includes some of these rules. First 
behavior is constrained. This challenges traders to respond to trading questions nearly instantly, to provide a narrow spread between the buying and selling prices, and to "make a price" (i.e., to trade) even when they stand to lose from the deal (this is what Baker once called their "affirmative obligation" [1984, p. 780] and was indicated by the rule of reciprocity discussed in the previous section). The constraints are imposed on precisely those parameters that traders might be inclined to manipulate to their advantage through behavior that lies somewhere between simple self-interest and opportunism - that is, self-interest with guile (Williamson 1981, pp. 553-54). For example, traders can increase the spread between the bid and the sell price to diminish their risk; they can delay their response, hoping, perhaps, that a caller will lose interest; they can simply limit their participation when the market goes against them; and they can tinker with the price (e.g., offer a price for a currency that they expect to go up that is higher than that which the market is currently offering, to induce others to sell to them and allow them to "go long" on an article that will be in demand; traders may also drive the price in a particular direction when they can "read" the counterparty's intention). However, consistently shaping the response in some of these ways may have relationship costs: a trader may lose prestige and his or her good reputation and may no longer be contacted. Then again, conforming to the code may also be problematic under some circumstances; for example, when a caller wants to distribute a trade across several banks and contacts them simultaneously, a trader who responds fast may lose. The counterparty may wait until all prices are in before disclosing the deal, not wanting a fast trader to learn about it early and make similar moves, which might destroy the market for the caller.

This reasoning reveals that participants' orientation toward the economic character of the transaction simultaneously involves them in an interactional and emotional dynamic that is inherent in trading conversations and discloses itself only when conversations collapse into more informal talk, as illustrated below. The tensions and conflicts associated with the opposing needs of buyer and seller and the conflicting demands of profit seeking and restraint are notable. Consider how this interactional dynamic may play itself out in a trading conversation. In the first part of the dynamic, the challenge, a caller's identity appears on the screen, followed by the indication of the size of a potential deal. If the caller

published in 1975 and periodically reissued, it does not deal with legal matters but "aims to set out the manner and spirit in which business should be conducted" (ACI 1996, p. 1). The 59-page booklet includes definitions and abbreviating conventions, addresses behavioral issues, and makes specific recommendations regarding confidentiality and dealing procedures. In addition to the published code, an informal code of honor is practiced, extending and interpreting the written code. 


\section{American Journal of Sociology}

works for a large hedge fund or an important investment bank, these lines may be received as a danger signal, which alerts the trader to potential market price movements that could be ignited by the caller's actions. The lines may also be received as a challenge to interpret the caller's undisclosed intent and to anticipate the market repositionings that may result from the completion of the deal; they may challenge the recipient to serve the caller well while they simultaneously challenge the recipient to calculate a price range that protects his or her position and also serves him or her well, which are two potentially conflicting goals. Traders meet these challenges by typing their commitment to a price range; they confront the danger and opportunity by entering an engagement. The second part of the dynamic begins with and is centered around this commitment, which leaves the trader exposed both to adverse market moves while waiting for the caller's response (e.g., changes in the market that would leave the trader "long" on a currency whose market price goes down) and to the risk that time and resources committed to a conversation might not end in a deal. In the following conversation, a side sequence exhibits the second part of the dynamic:

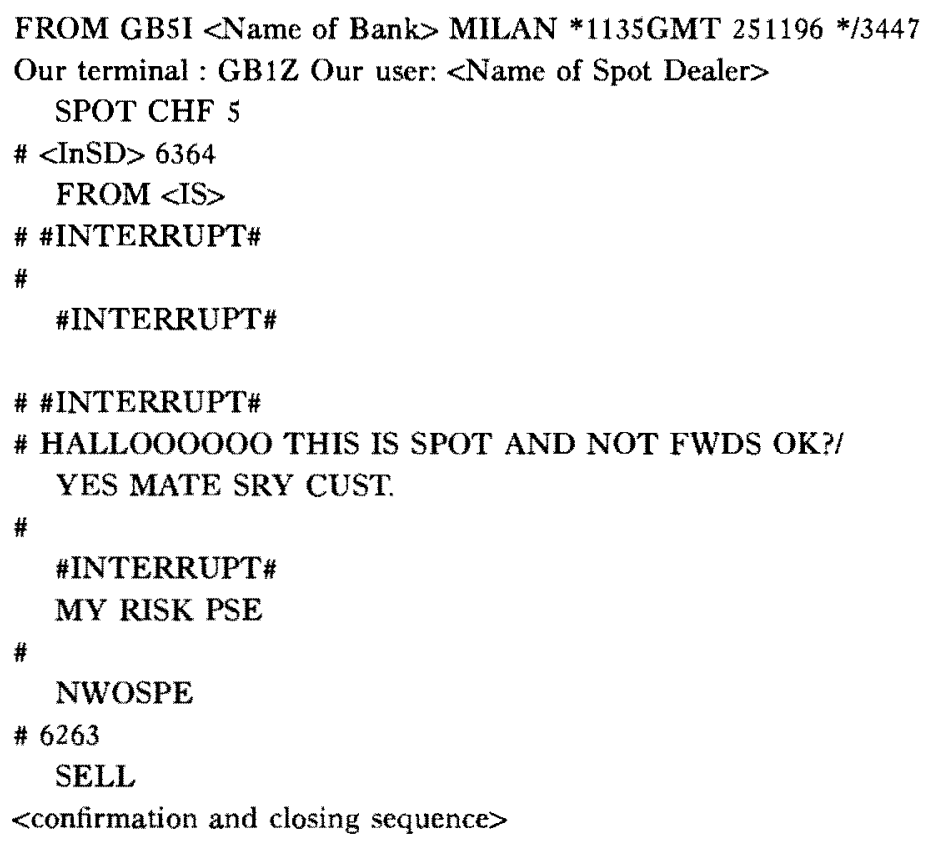

In this conversation, the trader, who was "king of the floor" in terms of earnings for the bank, reputation among traders, and importance of the currency traded, offers a narrow price range (line 4 ). The trader is then 
kept waiting by the caller, who does not respond and tries to snatch the turn back from him (line 8) while the trader also holds on to it or also interrupts (lines 6 and 10). This back and forth ends when the Zurich trader interjects an angry reprimand ("HALLOOOOOO THIS IS SPOT AND NOT FWDS OK?"), thereby reminding the caller that, in spot trading, rather than situations in which long-term instruments are traded, a response must come forth immediately. The caller, accepting this, apologizes by asserting that he himself was kept waiting by a customer who had not reached a decision (line 12 means "Yes, mate; sorry, customer"). The caller interrupts the flow once more and then offers "MY RISK PL[EA]SE" - meaning that he considers the Zurich trader no longer committed to the price. The caller accordingly repeats the price question when ready ("NWOPSE," a misspelled and abbreviated form of "Now please," (line 17]), receives a new price offer with an equally narrow spread (6263), and agrees to the deal ("SELL").

The conversational turbulence and repair shows how the conventions of global conduct are interactionally upheld. Note again that, unlike other exchange situations, interactional means play no role here in the establishment and negotiating of situational outcomes, for example, price or buying commitments. Rather, they are used to manage and sustain a global order-through a variety of means of the sort indicated, which include overtly stating that one is noting someone's misbehavior or asserting the break off of the business relationship. It is this structural, rather than situational, deployment of interactional means for the maintenance of a social form that we want to introduce as another aspect of global microstructures. This deployment occurs in a domain where legal sanctions are almost entirely unavailable and would be considered inefficient by participants.

\section{The Bodily Anchoring of Response-Presence-Based Interactions}

A further microstructural element that also enters into view with the interactional dynamic of trading takes us back to the notion of the faceto-screen situation. Consider that the profits and losses that spot traders make are marked to them individually at the end of every day; they are also marked to them as their contribution to the desk (i.e., the group of traders dealing in the same instrument at a particular location). Traders keep track of their profit and loss balance with practically every trade; their worth is explicit not only to themselves but also to their supervisors, at every moment in time. In this situation, the trader puts his or her self on the line with every move. In particular, losses promote fear and perhaps greed and are expressed in a vocabulary that resounds with the emotions of perceived violence and attack. As a trader on the Zurich floor put it, 
the terms refer "basically [to] sex and violence and a lot of them seem to have to do with anal penetration." The list that we accumulated included "I got shafted," "I got bent over," "I got blown up," "I got raped," "I got stuffed"/"the guy stuffed me," "I got fucked," "I got hammered," and "I got killed."

One interesting facet of this vocabulary is that it displays the assaults implicit in global-trading conversations as being analogous to bodily assaults. Goffman took it to be evident that we could, as he put it, "participate in social situations only if we bring our bodies and their accoutrements along with us," and he saw this equipment as vulnerable to physical assault, sexual molestation, and so on, by virtue of the instrumentalities that others bring along with their bodies $(1983$, p. 4). Traders think of their market presence in terms of "exposures" and "vulnerabilities," talking, for example, about upside and downside exposures to markets by virtue of being long or short on a currency from whose price direction they stand to lose money. On record-keeping forms initiating parties were called "aggressors," while traders quoting prices were called "nonaggressors." Beyond indicating economic danger, the vocabulary of aggression and assault displays traders' emotional engagement with the market and other market participants. Participants appear to be viscerally plugged into the screen reality and indicate this when they refer to market actions in terms of the penetration of their bodily preserves. One way to make sense of this perceived physical connectedness is by returning once more to the established setup of a trading desk. Through their face and body front, traders reorient a significant fraction of their sensory equipment and bodily reaction capabilities to the life-form of the market-that is, to its glaring and eye-catching presence on screens, its continual vocal demands (phone, voice broker), and the effect it has of rousing other traders to sometimes-frantic action. Although traders are not able to slip through the screen and walk into this life-form, they stand within its intimate space, close enough to feel every tick of its movements and to tremble and shake whenever it trembles and shakes. Perhaps we may think of a trader's reactions to the market in terms of Mead's (1934, pp. 144-48) description of a conversation of gestures: reflexlike actions that mirror market movements and respond to them and are possible only in a situation of sensory attunement and attachment to a copresent other. The market, we argue, is, for those engaged with it, a copresent other; in this sense, the face-to-screen situation retains characteristics of a physical response setting continuous with the face-to-face situation (see Goffman 1983, p. 2). 


\section{THE COMMERCE OF KNOWLEDGE}

We have now established our understanding of global microstructures on two levels. First, we can assume a measure of background integration of global markets as social systems that corresponds to a form of intersubjectivity, a microcoordination of consciousness that is equivalent to and extended beyond that which is possible in the face-to-face situation. Second, on a performative level, these markets appear to be patterned in terms of structures (e.g., conversation structures) and mechanisms (e.g., interactional mechanisms of social governance) that extend this microcoordination. We now want to enrich our scheme by adding a second type of commerce-that is, a pattern of interaction dealing in knowledge-to the dealing commerce discussed. This allows us to reemphasize, if only selectively and briefly, one aspect of the markets studied that was present in much of what was said before-that is, the markets' deep intersection with knowledge. The flow of observations that holds these markets together entails flows of knowledge; the coordination of consciousness that we have postulated intersects with an exchange of knowledge. Equally, contentwise, the dealing conversations we have indicated and, more generally, nearly all nondealing conversations, involve exchanges of knowledge.

In daily activities, this second type of commerce lays the groundwork for the first type. Traders in any time zone start their day by exchanging information with their colleagues in the previous time zone. They also keep some conversations open on screen throughout the day; here, intermittent with trading, they continually exchange information. A basic reason for this second type of commerce as an ongoing activity lies in that traders cannot, within the split seconds in which they make dealing decisions, search for the relevant information; they must have it "ready to hand." To maintain a state of preinformation, traders continually engage in knowledge work, in addition to making economic transactions. The two areas into which traders' work is divided correspond to two kinds of "commerce" (Zelizer 2000), in the following sense: while traders' economic transactions involve them in the exchange of goods for money, traders' knowledge work involves them in a reciprocal gift exchange (e.g., Bourdieu 1977; Hochschild 1989); traders continually offer information to others without requesting immediate payments. They also receive information in return, within generalized and specific (i.e., dyadic) circuits of information. When the two kinds of commerce come together in dealing conversations, they occupy different positions and follow different patterns. For example, information is offered during or after a beginning or ending sequence, never during the actual engagement. The commerce of knowledge may also take priority over the commerce of currencies. A 


\section{American Journal of Sociology}

dealer may give priority to the knowledge he or she obtains and may conduct business with the intent of nurturing the information relationship.

Before illustrating this pattern, we want to emphasize the existence of such relationships. The idea of relational embeddedness postulates that exchange tends to flow through interpersonal and interorganizational relationships that are based on rules of trust, exclusivity, and loyalty which structure markets and influence exchange outcomes (e.g., Granovetter 1985; White 1981 b, p. 543; Baker 1981; Uzzi 1997; Fligstein and MaraDrita 1996, pp. 14-15; Baker, Faulkner, and Fisher 1998, pp. 148-50). In the present context, we can broadly distinguish between situations in which traders do not know the caller contacting them (they will generally know the institution, which must be accredited with their bank) and those in which they do know the caller, although they may not have met in person. When deals are made via the EBS, the former situation is more common. Conversely, deals through the Reuters conversational dealing system involve more relationships of familiarity and trust. The system infrastructure used shapes the interaction in the sense that it enables and encourages or discourages the emergence of relationships. Since traders routinely have both systems available, they may choose the Reuters conversational dealing system for relationship deals and EBS for others deals, or they may complement EBS deals with conversations conducted via the Reuters dealing system. ${ }^{17}$ When relationships are involved, they act as conduits for the flow of knowledge and information. All relationships in which traders are engaged appear to be information relationships; many also involve trades and personal exchanges. To turn the argument around, gifts of knowledge and information are the means of relationship building when it comes to the disembedded global markets studied. Previous faceto-face contacts, on the other hand, are not necessary for the establishment of dealing relationships that involve familiarity, trust, and the exchange of personal information; in fact, face-to-face contacts often follow, rather than precede, electronically mediated relationships.

The dual organization of traders' activities into dealing and knowledge work is clearly marked in the following interaction. Also clearly marked is the underlying relationship, which illustrates a global tie in which the maintenance of the information relationship takes priority over profic making, according to the interpretation we obtained. The deal is between

\footnotetext{
${ }^{17}$ We cannot give quantitative information about the percentage of deals that involve long-standing relationships. This percentage varies over time; depends on market liquidity, trading strategy; and the bank involved; and has shifted since the introduction of the euro toward more deals being done through the EBS-although traders from $\mathrm{GB} 2$ (the last ones interviewed) see this trend as leveling off.
} 
a trader at a very large and important American global investment bank and Zurich's dollar-Swiss franc trader:

1 $251196 * / 3514$

2 Our terminal: GB1Z Our user : < Name of Spot Dealer $>$

3 \# TEST BACK LOWER RATES NOW .....

$4 \quad \#$

5 \#INTERRUPT\#

6 CAN I GIVE YOU 15 MIO USDCHF PLS

7 \# SURE 83

8 GTEATEE TREE GREAT. TKS

9 \# WELCOME . . .

10 \# BUYING DM SFR HERE ...

11 \#AROUND 150 MI. . . . .

12 BUT LOOKS DAMN TOPPSIH HERE. . . THINKING <GB4>

13 ... ON THE TOP

Note that the central conventions of global trading are ostentatiously broken in the deal: the caller discloses his intention instead of keeping it silent (he requests to sell \$15 million against Swiss francs [line 6]), obtains only a one-way price (line 7), thanks the Zurich trader at the point where the standard pattern features the deal selection of "GREAT" and "T[HAN]KS" are misspelled [line 8]), and is greeted by a "WELCOME" (line 9) that ignores the prescribed confirmation sequence. What this means is that the two parties affirm, through the specific formulations used, that they have a long-standing relationship that is based on trust and needs no precautions and formalities. They also begin the conversation with an information exchange, which they continue after the deal is completed. The Zurich trader offers information that is actually a warning: he says the dollar is moving lower, after which the London dealer makes his selling request (line 3 ). He also offers the information about a German mark-Swiss franc transaction (lines 10-12; for details, see "Reciprocity as a Requirement of Intersubjectivity," above).

Personal knowledge is also involved in the relationships described and defines them as business connections that are, at the same time, personal ties. The two components run together, and they also become deeply intertwined with the informational content we have described. In the deal discussed above, this informational content resides in the observations that the Zurich trader offers in lines 3 and 10-12, but it also resides in the deal itself, which contributes to the Zurich trader's picture of the market by telling him more about how a significant market participant 


\section{American Journal of Sociology}

moves his positions and places his bets. The return gift that the Zurich trader obtains, for his gifts of information, is not just a business deal. By linking themselves in deals with important market actors, traders are able to track the market "as it is made"; they gain bits and pieces of information before others and are able to assess future trading opportunities and constraints from the positions that their counterparties have taken. In the above deal, the Zurich trader returns the gift by offering a good price, as well as local knowledge from the trading room in Zurich and his position in the screen world.

\section{CONCLUSION}

Among the regular microstructural patterns we have describedincluding the reciprocal interlocking of time dimensions among actors constituted as observers, conversation structures as a performative means for global transaction and relatedness, the structural use of interaction devices, bodily anchoring, and the grounding of activities in a commerce of knowledge-the first of these patterns was in a sense the most central. The reciprocal interlocking of time dimensions has brought into view a level of intersubjectivity that points beyond network perspectives as a key to the question of the inherent connectivity and integration of global markets as social forms. The elaborate temporal structuration and observation of a common object, the market, is also what most probably distinguishes global intersubjective fields from groups that hold electronic meetings for the purpose of either discussion or engaging in identity games and untried forms of interaction (e.g., Turkle 1995). While we have assumed that the markets studied foreshadow patterns that will also emerge in other genuinely global forms, we also expect that virtual groups display variability not only in group purposes but also in their form of social coordination. According to the literature, the ways in which electronic gatherings are temporally structured are limited and do not display the patterns that we have identified (Walther 1996; Baym 1998, p. 43). ${ }^{18}$ Similarly, the intense, reciprocal observations that characterize the markets studied appear not to be matched by related activities in Internet relay

\footnotetext{
${ }^{18}$ Analysts distinguish between synchronistic and asynchronistic communication on the basis of whether participants are on-line simultaneously and reading and responding to messages from one another immediately or at different times, respectively. They also distinguish between groups meeting only once for a limited time synchronically or asynchronically, groups having a series of meetings in either of these ways, and groups having continual asynchronistic meetings over an extended time period. The groups discussed herein have continual synchronic interactions over an unlimited time period, and the temporal dimensions that we described structure their synchronic interactions.
} 
chats, multiuser domains, and other groups (Jones 1998). Perhaps the most intricate forms of global microintegration in response-presence-based social forms can indeed be found in global financial markets, which are highly disembedded social systems, and whose system infrastructures surely are among the best developed-and the best serviced - in the world. Alternative patterns of global integration can presumably be found in global scientific collaborations that rely on centered sites and centering mechanisms of cultural production (e.g., high-energy physics experiments conducted by 2,000 physicists worldwide and lasting 20 years; see Knorr Cetina 1999, chaps. 7-8) and in some globally operating terrorist organizations, which seem to be characterized by a strong level of intersubjectivity that is combined with dispersed activities and distantiated cooperations. The existence of such alternative forms of coordination and the questions raised by electronic groups call for comparative research that investigates the changing features of sociality as it takes shape in conjunction with processes of globalization.

\section{REFERENCES}

Abolafia, Mitchel Y. 1996a. "Hyper-rational Gaming." Joumal of Contemporary Ethnography 25 (2): 226-50. 1996b. Making Markets: Opportunism and Resiraint on Wall Street. Cambridge, Mass: Harvard University Press. 1998. "Markets as Cultures: An Ethnographic Approach." Pp. 69-85 in The Laws of the Markets, edited by Michel Callon. Oxford: Blackwell.

Agnew, J. 1986. Worlds Apart: The Market and the Theater in Anglo-American Thought, 1550-1750. New York: Cambridge University Press.

Association Cambiste Internationale. 1996. Code of Conduct. Paris: Kremer-Muller \& Cie, Foetz.

Austin, John L. 1962. How to Do Things with Words. Oxford: Oxford University Press.

Baker, Wayne E, 1981. "Markets as Networks: A Multimethod Study of Trading Networks in a Securities Market." Ph.D, dissertation. Northwestern University, Department of Sociology.

. 1984. "The Social Structure of a National Securities Market." American Joumal of Sociology 89 (4): $775-811$.

- 1990. "Market Networks and Corporate Behavior" American Journal of Sociology 96:589-625.

Baker, Wayne E., Robert R. Faulkner, and Gene A. Fisher. 1998. "Hazards of the Market: The Continuity and Dissolution of Interorganizational Market Relationships." American Sociological Review 63:147-77.

BIS (Bank for International Settlements). 1998. "Central Bank Survey of Foreign Exchange and Derivatives Market Activity in April 1998: Preliminary Global Data." Basel: BIS.

Barber, B. 1995. "All Economies Are 'Embedded': The Career of a Concept and Beyond." Social Research 62:387-413.

Baron, James N., and Michael T. Hannan. 1994. "The Impact of Economics on Contemporary Sociology." Joumal of Economic Literature 32 (3): 111-46.

Baym, Nancy. 1998. "The Emergence of Non-line Community." Pp. 35-68 in 
Cybersociety 2.0: Revisiting Computer-Mediated Communication and Community, edited by Steven G. Jones. Thousand Oaks, Calif.: Sage.

Blumer, Herbert. 1967. Symbolic Interaction. Englewood Cliffs, N.J.: Prentice Hall.

Boden, Deidre. 1994. The Business of Talk: Organizations in Action. Cambridge: Polity Press.

Bodie, Zvi, and Robert C. Merton. 1995. "The Informational Role of Asset Prices: The Case of Implied Volatility." Pp. 197-224 in The Global Financial System, edited by D. B. Crane et al. Boston: Harvard Business School Press.

Bourdieu, Pierre. 1977. Outline of a Theory of Practice. Cambridge: Cambridge University Press.

Bruegger, Urs. 1999. "Wie handeln Händler? Akteure der Globalisierung." Ph.D. dissertation. University St. Gallen.

Budd, L., and S. Whimster, eds. 1992. Global Finance and Urban Living. London: Routledge.

Burt, Ronald. 1983. Corporate Profits and Cooptation: Networks of Market Constraints and Directorate Ties in the American Economy. New York: Academic Press.

Button, Graham, ed. 1993. Technology in Working Order. London: Routledge.

Callon, Michel. 1998. "An Essay on Framing and Overflowing: Economic Externalities Revisited by Sociology." Pp. 244-69 in The Laws of the Markets, edited by Michel Callon. Oxford: Blackwell.

Campbell, Colin. 1996. The Myth of Social Action. Cambridge: Cambridge University Press.

Carruthers, Bruce, and Brian Uzzi, 2000. "Economic Sociology in the New Millennium." Contemporary Sociology 29 (3): 486-94.

Caves, R. E, J. A. Frankel, and R. W. Jones. 1999. World Trade and Payments, 8th ed. Reading, Mass: Addison-Wesley Publishing.

Clark, Colin, and Trevor Pinch. 1995. The Hard Sell: The Language and Lessons of Street-wise Marketing. London: Harper Collins.

Coase, R. H. 1937. "The Nature of the Firm." Economica 4:386-405.

Collins, Randall. 1981. "Micro-translation as a Theory-Building Strategy." Pp. 81-108 in Advances in Social Theory and Methodology: Toward an Integration of Microand Macro-sociologies, edited by Karin Knorr Cetina and Aaron Cicourel. London: Routledge \& Kegan Paul. 1988. Theoretical Sociology. San Diego: Harcourt Brace Jovanovich.

Crane, D., et al. 1995. The Global Financial System. Boston: Harvard Business School Press.

DeLaPradelle, Michèle. 1995. "Market Exchange and the Social Construction of a Public Space." French Cultural Studies 6:359-71.

DiMaggio, Paul. 1994. "Culture and the Economy." Pp. 27-57 in The Handbook of Economic Sociology, edited by Neil Smelser and Richard Swedberg. Princeton, N.J.: Princeton University Press.

2001. "Introduction: Making Sense of the Contemporary Firm and Prefiguring Its Future." Pp. 3-30 in The 21st Century Firm, edited by Paul DiMaggio. Princeton, N.J.: Princeton University Press.

DiMaggio, Paul, and H. Louch. 1998. "Socially Embedded Consumer Transactions: For What Sorts of Purchases Do People Use Networks Most?" American Sociological Review 63 (5): 619-37.

Dormael, Armand van. 1997. The Power of Money. New York: New York University Press.

Drew, Paul, and John Heritage. 1992. Talk at Work: Interaction in Institutional Settings. Cambridge: Cambridge University Press

Durkheim, Émile. (1893) 1964. The Division of Labor in Society. New York: Free Press. 
Dutton, William H., ed. 1996. Informalion and Communication Technologies: Visions and Realities. Oxford: Oxford University Press.

Euromoney: 2000. May, p. 52.

Fine, Gary Alan. 1984. "Negotiated Orders and Organizational Cultures." Annual Review of Sociology 10;239-62.

Fisher, I. 1907. The Rate of Interest. New York: Macmillan. 1930. The Theory of Interest. New York: Macmillan.

Fligstein, Neil. 1990. The Transformation of Corporate Control. Cambridge, Mass.: Harvard University Press.

1996. "Markets as Politics: A Political-Cultural Approach to Market Institutions." American Sociological Review 61:656-73.

Fligstein, Neil, and Iona Mara-Drita. 1996. "How to Make a Market: Reflections on the Attempt to Create a Single Market in the European Union." American Joumal of Sociology 102 (1): 1-33.

FX Week. 1998. June 1, vol. 9, no. 22.

Garfinkel, Harold 1967. Studies in Ethnomethodology. Englewood Cliffs, N.J.: Prentice Hall.

Garfinkel, Harold, Michael Lynch, and E. Livingston. 1981. "The Work of Discovering Science Constructed with Material from the Optically Discovered Pulsar." Philosophy of the Social Sciences 11:131-58.

Geertz, Clifford. 1978. "The Bazaar Economy: Information and Search in Peasant Marketing." Supplement to the American Economic Revieve 68:28-32.

Giddens, Anthony. 1990. The Consequences of Modemily. Stanford, Calif: Stanford University Press.

Goffman, Erving. 1972, "The Neglected Situation." Pp. 61-66 in Language and Social Context, edited by P. P. Giglioli. Harmondsworth: Penguin. 1981. "Response Cries." Pp. 78-123 in Forms of Talk. Philadelphia: University of Pennsylvania Press.

1983. "The Interaction Order." American Sociological Review 48:1-17.

Goodhart, Charles. 1988. "The Foreign Exchange Market: A Randorn Walk with a Dragging Anchor." Economica 55:437-60.

Goodwin, Charles. 1995. "Seeing in Depth." Social Studies of Science 25:237-74.

Gosh, D. K., and E. Ortiz, eds. 1997. The Global Structure of Financial Markets. New York: Routledge

Granovetter, Mark. 1985. "Economic Action and Social Structure: The Problem of Embeddedness." American Joumal of Sociology 91 (3): 481-510.

Gyöngyössy, Istran. 1984. International Money Flows and Currency Crises. The Hague: Martinus Nijhoff.

Hamilton, Adrian. 1986. The Financial Revolution. New York: Free Press.

Harvey, D. 1989. The Condition of Postmodernity: An Inquiry inte the Origins of Cultural Change. New York: Blackwell.

Hayek, F. A. 1945. "The Use of the Knowledge in Society." American Economic Review 35 (4): $519-30$.

Heath, Christian, Marina Jirotka, Paul Luff, and Jon Hindmarsh. 1994. "Unpacking Collaboration: The International Organisation of Trading in a City Dealing Room." Journal of Computer Supported Cooperative Work 3:147-65.

Hills, Clara A., Peter G. Peterson, and Morris Goldstein. 1999. Safeguarding Prosperity in a Global Financial Architecture. New York: Institute for International Economics.

Hochschild, Arlie R. 1989. "The Economy of Gratitude." Pp. 95-111 in The Sociology of Emotions: Original Essays and Research Papers, edited by D. D. Franks and Th. Hood. Greenwich, Conn.: JAI Press.

Jones, Steven G., ed. 1998. Cybersociety 2.0: Revisiting Compuler-Mediated Communication and Community. Thousand Oaks, Calif.: Sage.

Knorr Cetina, Karin. 1981. "Introduction." Pp. 1-47 in Advances in Social Theory and 


\section{American Journal of Sociology}

Methodology: Toward and Integration of Micro- and Macro-Sociologies, edited by Karin Knorr Cetina and Aaron Cicourel. London: Routledge \& Kegan Paul. 1999. Epistemic Cultures: How the Sciences Make Knowledge. Cambridge, Mass.: Harvard University Press.

Knorr Cetina, Karin, and Urs Bruegger. 2002a. "Inhabiting Technology: Features of a Global Lifeform." Current Sociology. Special issue "The Sociology of Technology." July (in press).

. 2002b. "Traders' Engagement with Markets: A Postsocial Relationship." Theory, Culture and Society, vol. 19 (in press).

Koundinya, Ramakrishnan S. 1997. "Exchange Rate Theories and the Behavior of Exchange Rates: The Record since Bretton Woods." Pp. 182-91 in The Global Structure of Financial Markets, edited by D. K. Gosh and E. Ortiz. New York: Routledge.

Leishon, Andrew, and Nigel Thrift. 1997. Money/Space: Geographies of Monetary Transformation. London: Routledge.

Mars, Frank. 1998. "Wir sind alle Seher." Ph.D. dissertation. University of Bielefeld, Faculty of Sociology.

McLuhan, Marshall. 1964. Understanding Media. London: Routledge.

Mead, George Herbert. 1934. Mind, Self and Society. Chicago: University of Chicago Press.

Mirowksi, Phil. 2002. Machine Dreams: Economics Becomes a Cyborg Science. Cambridge: Cambridge University Press.

Natanson, Maurice. 1962. Introduction to Collected Papers. Vol. 1: The Problem of Social Reality by Alfred Schutz. The Hague: Nijhoff.

Nicholson, Colin. 1994. Writing and the Rise of Finance. Cambridge: Cambridge University Press.

Perold, André F. 1995. "The Payment System and Derivative Instruments." Pp. 33-80 in The Global Financial System, edited by D. Crane et al. Boston: Harvard Business School Press.

Portes, Alejandro. 1995. "Economic Sociology and the Sociology of Immigration: A Conceptual Overview." Pp. 1-41 in The Economic Sociology of Immigration, edited by Alejandro Portes. New York: Russell Sage Foundation.

Powell, Walter. 1990. "Neither Market nor Hierarchy: Network Forms of Organization." Research in Organizational Behavior 12:295-336.

Preda, Alex. 2001. "In the Enchanted Grove: Financial Knowledge and the Marketplace in England and France in the 18th Century." Joumal of Historical Sociology 14 (3): 276-307.

Read, Donald. 1992. The Power of News: The History of Reuters. Oxford: Oxford University Press.

Sassen, Saskia. 2001. The Global City, 2d ed. Princeton, N.J.: Princeton University Press.

Scheff, Thomas J. 1990. Microsociology. Chicago: University of Chicago Press.

Schutz, Alfred. 1964. Collected Papers II: Studies in Social Theory, edited and introduced by Arvid Broodersen. The Hague: Nijhoff.

1967. The Phenomenology of the Social World. Evanston, 1ll.: Northwestern University Press.

Schutz, Alfred, and Thomas Luckmann. 1973. The Structures of the Life-World. Evanston, 1ll.: Northwestern University Press.

Shiller, Robert J. 2000. Irrational Exuberance. Princeton, N.J.: Princeton University Press.

Smelser, Neil, and Richard Swedberg, eds. 1994. Handbook of Economic Sociology. Princeton, N.J.: Princeton University Press.

Smith, Charles W. 1981. The Mind of the Market. London: Croom Helm. 
1990. Auctions: The Social Construction of Value. Berkeley and Los Angeles: University of California Press.

1999. Success and Survival on Wall Street: Understanding the Mind of the Market. New York: Rowman \& Littlefield.

Soros, George. 1994. The Alchemy of Finance. New York: Wiley \& Sons.

Stark, David. 1998. "Recombinant Property in East European Capitalism." Pp. 116-46 in The Laws of the Markets, edited by Michel Callon. Oxford: Blackwell.

Stone, Gregory P., and Harvey A. Farberman. 1981. Social Psychology through Symbolic Interaction. New York: Wiley \& Sons.

Strange, Susan. 1988. States and Markets. London: Pinter.

Suchman, Lucy A. 1987, Plans and Situated Actions: The Problem of Human-Machine Communication. Cambridge: Cambridge University Press.

Swedberg, Richard. 1991. "Major Traditions of Economic Sociology." Annual Review of Sociology 17:251-76.

. 1997. "New Economic Sociology: What Has Been Accomplished, What Is Ahead?" Acta Sociologica 40:161-82.

Swedberg, Richard, and Mark Granovetter. 1992. "Introduction." Pp. 1-26 in The Sociology of Economic Life, edited by Mark Granovetter and Richard Swedberg. Boulder, Colo.: Westview Press.

Ten Have, Paul, and George Psathas, eds. 1995. Situated Order. Washington, D.C.: International Institute for Ethnomethodology and Conversation Analysis and University Press of America.

Thaler, Richard H., ed. 1993. Advances in Behavioral Finance. New York: Russell Sage Foundation.

Thevenot, Laurent. 2001. "Pragmatic Regimes Governing the Engagement with the World." Pp. 56-73 in The Practice Turn in Contemporary Theory, edited by Theodore R. Schatzki, Karin Knorr Cetina, and Eike von Savigny. London: Routledge.

Turkle, Sherry. 1995. Life on the Screen. New York: Simon \& Schuster.

Uzzi, Brian. 1997. "Social Structure and Competition in Interfirm Networks: The Paradox of Embeddedness." Administrative Science Quarterly 42:35-67.

1999. "Embeddedness in the Making of Financial Capital: How Social Relations and Networks Benefit Firms Seeking Financing." American Sociological Review 64:481-505.

Walther, J. 1996. "Computer-Mediated Communication: Impersonal, Interpersonal and Hyperpersonal Interaction." Communicalion Research 23 (1): 3-43.

White, Harrison, 1981a. "Production Markets as induced Role Structures." Pp. 1-57 in Sociological Methodology, edited by Samuel Leinhardt. San Francisco: JosseyBass Publishers.

1981b. "Where Do Markets Come From?" American Joumal of Sociology 87: $517-47$

1992. Identity and Control: A Structural Theory of Social Action. Princeton, N.J.: Princeton University Press.

- 1993. "Markets as Production Networks." Pp. 161-75 in Exploralions in Economic Sociology, edited by Richard Swedberg. New York: Russell Sage Foundation.

Wiley, Norbert. 1994. The Semiotic Self. Chicago: University of Chicago Press.

Williamson, Oliver E. 1975. Markets and Hierarchies: Analysis and Antitrust Implications. New York: Free Press.

. 1981. "The Economics of Organization; The Transaction Cost Approach." American Joumal of Sociology 87:548-77.

1985. The Economic Institutions of Capitalism, Firms, Markets, Relational Contracting. New York: Free Press.

Zaner, Richard. 1964. The Problem of Embodiment: Some Contributions to a Phenomenology of the Body. The Hague: Nijhoff. 
American Journal of Sociology

Zelizer, Viviana. 1988. "Beyond the Polemics on the Markets: Establishing a Theoretical and Empirical Agenda." Sociological Forum 3:614-34.

2000. "Uniform Money and Variable Practice." Paper presented at the annual meeting of the American Sociological Association, Washington, D.C., August 12-16. Zerubiavel, Eviatar. 1981. Hidden Rhylhms: Schedules and Calendars in Social Life. Berkeley and Los Angeles: University of California Press.

1982. "The Standardization of Time: A Sociohistorical Perspective." American Joumal of Sociology 88 (1): 1-23. 